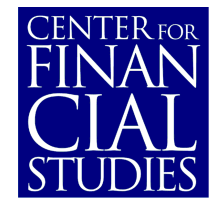

No. $2001 / 07$

\title{
How Wide Are European Borders? New Evidence on the Integration Effects of Monetary Unions
}

Guenter Beck / Axel A. Weber

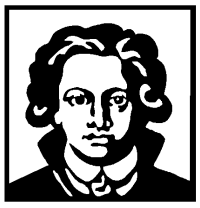

Center for Financial Studies 


\title{
How Wide Are European Borders? New Evidence on the Integration Effects of Monetary Unions
}

\author{
Guenter Beck (University of Frankfurt) and \\ Axel A. Weber (University of Frankfurt, Center for Financial Studies, and CEPR)*
}

January 2001

\begin{abstract}
:
We use consumer price data for 81 European cities (in Germany, Austria, Switzerland, Italy, Spain and Portugal) to study deviations from the law-of-one-price before and during the European Economic and Monetary Union (EMU) by analysing both aggregate and disaggregate CPI data for 7 categories of goods we find that the distance between cities explains a significant amount of the variation in the prices of similar goods in different locations. We also find that the variation of the relative price is much higher for two cities located in different countries than for two equidistant cities in the same country. Under EMU, the elimination of nominal exchange rate volatility has largely reduced these border effects, but distance and border still matter for intra-European relative price volatility.
\end{abstract}

Keywords: relative price volatility, spatial data, real exchange rate, law of one price, purchasing power parity, stationarity, panel unit root test

JEL classification: F40, F41

*) This work is part of a CFS research programme on Monetary Policy in Europe. It is also part of a CEPR research and training network on Understanding Europe's Role in the Global Economy. Financial support by the Center for Financial Studies and the Commission of the European Communities is gratefully acknowledged. The usual disclaimer applies. 


\section{Introduction}

Recent research has aimed at improving our understanding of the magnitude and determinants of deviations from the law-of-one-price (LOOP). One strand of the literature estimates the half-lives of real exchange rates. For most countries and time periods, real exchange rates are found to be highly persistent, with deviations from PPP amongst industrialised nations having half-lives of several years. A second approach focuses on the comparison of movements in goods prices across national borders to price movements between different regions within a country. A seminal paper by Engel and Rogers (1996) finds that both distance and the border are significant in explaining relative price dispersion in 10 U.S. and 9 Canadian locations. They show that (i) relative price variability increases with distance within each country and (ii) U.S.-Canadian relative price variability is significantly larger than within-country variability. They provide a useful measure of how important the border is relative to distance — the "width of the border". Their estimates suggest that crossing the U.S.-Canadian border is equivalent to 1,780 miles of distance, that is, in order to generate the same degree of relative price volatility by distance within a countries, the cities would have to be 1,780 miles apart. By this "width of the border" metric, international failures of the law of one price are large.

The role of borders and geography has increasingly received more attention in economics and a number of recent papers have discovered evidence of such border effects for various alternative categories of goods ${ }^{1}$ and for additional locations. Engel, Hendickson and Rogers (1977) and Parsley and Wei (2000) use data from North America, Asia and Europe to study intra-national, intra-continental and intra-planetary deviation from the lawof-one-price, whilst Engel and Rogers (2000) and Rogers, Hufbauer and Wada (2001) focus exclusively on European locations. In all of these studies only a few intra-national 
locations are used and the prime focus is on national data with cities being identified as the nations' capitals. A large number of truly intra-national data are used in Beck and Weber (2001a). We augment the Engel and Rogers (1996) data set by regional price level data from 26 Mexican cities, 47 Japanese prefectures, 12 cities in New Zealand and 10 cities in Australia. Like Engel, Hendickson and Rogers (1977) we find a much larger effect for the inter-continental (trans-Pacific) city pairs as compared to the North-American intracontinental city pairs.

In this paper we examine the importance of both distance and national borders between locations in determining the degree of the failure of the law of one price (LOOP) in Europe. We employ both aggregated CPI data and dis-aggregated data for 7 categories of consumer goods. We make use of regional data available within the European Union (EU) for 12 German, 20 Austrian, 4 Swiss, 20 Italian, 18 Spanish and 7 Portugese cities. For these 81 European cities we are able to analyse movements of $3240(=81 *(81-1) / 2)$ relative prices. These data are taken from the SPATDAT@ databank, ${ }^{2}$ which is by far the largest cross-sectional data set used in this literature for Europe to date.

The specific focus of the current paper is on the integration effects arising from the formation of monetary unions. For this purpose we study the German and European monetary unification (GEMU and EMU) process in more detail. With the fall of the Berlin wall in September 1989 the formerly divided East and West Germany de facto became one single country. German economic and monetary unification occurred shortly afterwards in July 1990, and in October 1990 political unification followed. Whilst these events jump-

\footnotetext{
${ }^{1}$ See Cruchini et al (199?) and O' Connel and Wei (199?) for a broad range of goods prices.

${ }^{2}$ SPATDAT $\odot$ is a CFS databank with spatial consumer price, wage and employment data for sub-national regions/districts/cities from a number of non-European OECD countries (U.S., Canada, Mexico, Japan, New Zealand, Australia) and Europe (Austria, Germany, Switzerland, Italy, Spain, Portugal, and Benelux). Both aggregate CPI data and data for a large number of disaggregate categories of consumer goods have been collected. Regional coverage within Europe is fairly broad (up to 80 Italian, 20 Austrian, 18 Spanish, 12 German, 7 Portugese and 4 Swiss locations will be used in the proposed study).
} 
started a process of economic integration, it is interesting to examine at what speed economic convergence and market integration took place. The present paper looks at relative price volatility across German cities in comparison to Austrian and Swiss locations in order to determine whether or not an East-West gap (or shadow-border effect) persisted even during GEMU. The second process of monetary unification we consider is the launching of the Euro on 1 January 1999, when the currencies of EMU member countries became irrevocably fixed on their way towards eventually disappearing from circulation in January 2002. As in the case of GEMU above, the effect of EMU on convergence and market integration will be studied by looking at the persistence of relative price volatility across 81 European cities in Germany, Austria, Switzerland, Italy, Spain, and Portugal.

Our estimation equations are similar to the ones used in Engel and Rogers (1996, 2000): the dependent variable is the variance of changes in the log of real exchange rate across cities, and among the explanatory variables are distance and "border" dummy variables. Since our European data set has city price data from several countries we are able to include in addition to distance simultaneously both a border dummy variable and a measure of nominal exchange rate variability in a regression explaining the variability of (common-currency) prices across cities. This allows us to assess separately the role of nominal exchange rate variability and the effects of a border. Our results indicate that most of the failures of the law of one price are attributable to currency volatility, but other barriers are also important explanatory factors. We find that, even taking into account nominal exchange rate variability, distance between cities and the border continue to have positive and significant effects on real exchange rate variability. However, these effects are small compared to the exchange rate volatility effect. 


\section{Data and Econometric Methodology}

As mentioned above, we use consumer price indexes from 81 locations in Europe. The data are monthly, covering the period January 1991 to June 2000 in the case of Germany, Switzerland and Austria, and January 1995 to June 2000 in the case of Italy, Spain and Portugal. Appendix Table 1 lists the locations in the six countries for which we have complied aggregate and dis-aggregate data. ${ }^{3}$ The seven dis-aggregated components of CPI cover categories of goods such as "food", "clothing", "furniture" or "transportation." The German data were obtained from the statistical offices of the individual Länder (states). The Italian data come from regular publications of the official government statistical agency ISTAT. For Spain, the data are on-line in the monthly statistical bulletin of the Spanish Instituto Nacional de Estadistica (INE), while the Federal Office for Statistics provided the data for Switzerland. For Austria the data were especially compiled for us by Statistics Austria (Oestat), and the Portugese data were obtained from Instituto Nacional de Estatistica (INE). Finally, the nominal exchange rates used in the study were taken from the IMF's International Financial Statistics database.

One novelty of the present paper the use of Austrian and Portugese data from cities within these countries and the use of East German in addition to West German city data. Another novelty is the use of dis-aggregate data on consumer price indices for European cities. Using price indices from 81 locations, we construct $3240(=81 * 80 / 2)$ bilateral relative prices. Our sample of six countries implies that the cross-border city pairs lie across one of $15(=6 * 5 / 2)$ national borders (that are not necessarily adjacent). There are two types of exchange rate arrangements determining the nominal exchange rates of our 15 country pairs. Germany was at the heart of the Exchange Rate Mechanism (ERM) of the European Monetary System (EMS), and adopted a policy of fixed but adjustable exchange rates with Austria, Italy, Spain and Portugal during the sample. Each of these five countries was included in the first wave of entrants into the Euro, launched in January 1999. Furthermore, all of these countries participated in the free-trade area of the European

\footnotetext{
${ }^{3}$ For the Benelux countries (Belgium, Luxembourg, the Netherlands), France, Denmark and Ireland we were unable to obtain sub-national data. Rather than following Engel and Rogers (2000) and using the national CPIs in those cases.we chose to exclude these countries from our analysis.
} 
Union (EU). Switzerland is the only country in our sample that has remained out of any formal arrangements on either exchange rates (ERM, EMU) or trade (EU). ${ }^{4}$

\section{II.1. Data Properties: Summary Statistics on Relative Volatility and Distance}

We denote the $\log$ of the CPI in location $j$ relative to that in location $k$ as $P(j, k)$. All prices are denominated in German marks. We are interested in explaining the volatility of changes in $P(j, k)$. We consider one-month changes in relative prices, $\Delta P(j, k)$ and we measure volatility as the sample variance, $V(\Delta P(j, k))$.

We construct our measure of volatility for each of the 3240 city pairs. Our regression analysis is then based on the cross-section of 3240 volatility measures. Table 1 presents some summary statistics. The rows report the average volatility of real exchange rates for all 6 pairs of locations that are both within Germany (ge-ge), Austria ( $a u-a u$ ), Switzerland (ch-ch), Italy (it-it), Spain ( $s p-s p)$ and Portugal $(p r-p r)$ as well as all 15 combinations of cross-border city pairs (ge-au, ge-ch, ge-it, ge-sp, ge-po, au-ch, au-it, au$s p$, au-po, ch-it, ch-sp, ch-po, it-sp, it-po, and sp-po). A key feature of our analysis is that we draw a distinction between cases where both locations are within the same country (labelled intra-national), and cases with one city in one country and the other city in a foreign country (labelled inter-national). For 1-month changes, the average volatility of cross-border pairs is typically considerably larger than the average variance of withincountry pairs. The within-Switzerland city pairs exhibit both the lowest average volatility and distance. Relative price volatility is slightly higher in Germany, followed by Italy, Spain, Austria and Portugal. Note that the volatility of relative prices across Portugese cities, equal to 4.17 , is roughly as high as the German-Austrian cross-border volatility, but except for this one case we typically find that within-country volatility is considerably

\footnotetext{
${ }^{4}$ The six countries used in this study also differ along geographic, linguistic, and cultural lines. In our sample Austria and Switzerland share a common border with three of the other countries (Germany, Italy and each other), whilst Germany has two adjacent neighbours (Austria and Switzerland) and Portugal and Spain only share a common border with each other. Note that our study takes explicit account of geographic considerations such as common borders or physical distance between locations. Finally, it is worth mentioning that common language factors may also matter. For example, German is spoken in 3 countries in our sample (Germany, Austria and Switzerland), while Portuguese, Spanish and Italian are languages specific to these countries. Like geography, these cultural factors may also contribute to economic integration between countries.
} 
lower than the average relative price volatility of the cross-border city pairs. This pattern of the volatility measures for the aggregate CPI index in Table 1 is in general matched by the volatility clusters for the dis-aggregate categories of goods, such as "food", "clothing", "furniture" or "transportation."

The two last rows of Table 1 display our measures nominal exchange rate volatility and distance. There is an obvious correspondence between relative price volatility, distance and nominal exchange rate volatility: for cross-border city pairs the volatility of nominal exchange rate changes, $\Delta s(j, k)$, in many cases is closely linked to relative price variability, a result that is well established in the literature. In our sample this holds for all crossborder combinations with Spain, Portugal and Switzerland, as is also shown in Figure 1. However, for Germany the 1-month average volatility of cross-border relative price changes vis-á-vis Austria is 4.13 , whilst the average volatility of nominal exchange rate changes is 0.49 , which is 10 times smaller. On the other hand, for Italy exchange rate volatility by far exceeds relative price volatility vis-á-vis all countries in Figure 1. This suggests that the link between relative price and nominal exchange rate volatility is less obvious than commonly expected. Another important stylized fact of the data can be seen from the last column of Table 1, which reports the average distance between locations. It shows that the more volatile cross-border city pairs are typically more distant than the within-country pairs.

Figure 2 displays this feature of the data graphically for the overall period 19952000. We find that in general relative price volatility between European city pairs located in the same country is lower than cross-border volatility, and that volatility increases with distance. However, whilst the low relative price volatility between German and Austrian city pairs indicates a high degree of integration, Figure 2 identifies lower degrees of goods market integration between Germany and Italy, followed by Spain and Portugal. As is to be expected, our measure of integration thereby declines with distance. The only exception from this pattern is found for Switzerland, which is a direct neighbour of Germany, Austria and Italy but neither a member of the ERM nor of the EU. Switzerland has the highest level of relative price volatility relative to all EU/ERM countries, and it's relative price volatility vis-á-vis Germany is by far larger than that of Italy, Spain or Portugal. Exchange 
rate volatility is the prime candidate for explaining this high Swiss-German border effect. ${ }^{5}$ In order to sort out the relative influence of these factors quantitatively, we now turn to our regression evidence.

\section{II.2. Regression Analysis}

Engel and Rogers $(1996,2000)$ examine the hypothesis that the volatility of the prices of similar goods sold in different locations is related to the distance between the locations and other explanatory variables, including a dummy variable for whether the cities are in different countries. Let $P_{j k}^{i}$ be the $\log$ of the price of good $i$ in location $j$ relative to the price of good $i$ in location $k$, whereby all prices have been converted into German mark using a monthly average exchange rate before taking relative prices. We then calculate the relative price volatility as the standard deviation of the difference in the log of relative prices between time $t$ and $t-1, V(\Delta P(j, k)$. This will be referred to as measure 1 in our analysis below, and we will perform robustness checks in which we employ a filtered measure (measure 2) and the spread between the 10th and 90th percentiles (measure 3) as alternative measures of volatility. Our results were essentially unaffected by the specific choice of the volatility measure.

In the analysis below we present the results of our estimates of regression equations of the form:

$$
V(\Delta P(j, k))=\Sigma \alpha(c) D(c)+\beta \log (d(j, k))+\delta B(j, k)+\gamma V(\Delta s(j, k))+u(j, k)
$$

or:

$$
V(\Delta P(j, k))=\Sigma \alpha(c) D(c)+\beta_{1} d(j, k)+\beta_{2} d(j, k)^{2}+\delta B(j, k)+\gamma V(\Delta s(j, k))+u(j, k)
$$

where $D(c)$ is a dummy variable for each city in our sample, $d(j, k)$ is the log distance between cities $j$ and $\mathrm{k}, B(j, k)$ is a dummy variable for each national border that separates cities $j$ and $\mathrm{k}$, and $V(\Delta s(j, k))$ is a measure of nominal exchange rate volatility between cities

\footnotetext{
5 The corresponding width-of-the-border measure may therefore be interpreted a welfare measure for Switzerland staying out of the EU and the ERM.
} 
$j$ and $\mathrm{k}$ located in different countries. Note that all regressions are cross-sectional, with 3240 observations. The inclusion of separate dummies for each individual location allows the variance of price changes to vary from city to city. That is, for city pair $(j, k)$ the dummy variables for city $\mathrm{j}$ and city $k$ take on values of 1 . There are a few reasons why we allow the level of the standard deviation to vary from city to city. First, there may be idiosyncratic measurement error or seasonalities in some cities that make their prices more volatile on average. Second, as Table 1 indicates, there seems to be somewhat higher average volatility for Austrian and Portugese cities than for Swiss or German cities. This may be because the Portugal and Austria are more heterogeneous countries. Either labour markets or goods markets may be less integrated, so there can be greater discrepancies in prices between locations. Alternatively, there may be differences in methodologies for recording prices that lead to greater discrepancies in prices between locations in one country compared to the other.

Following Engel and Rogers (1996) we assume that relative price volatility will be larger the greater the distance $d(j, k)$ between locations, due to "transportation costs." The key argument here is that in the presence of transportation costs prices in one location are not necessarily equalized with prices in another location, and that the relative price could fluctuate in a range which is likely to be a function of the transportation cost and hence the distance between the locations. Equation (1) postulates that more distant locations would have greater price dispersion. We postulate either a log-linear $\beta>0)$ or a concave $\left(\beta_{1}>0\right.$ and $\beta_{2}<0$ ) relationship between distance and relative price volatility, and we interpret "transportation costs" liberally to include any factors that make it more costly to sell goods in one location compared to another. ${ }^{6}$

We are furthermore particularly interested in whether there is a border effect. We expect the variability of prices between cities that lie across a border to be higher than those between cities within a country, even after accounting for the effect of distance and nominal exchange rate volatility. The recent literature on pricing to market has examined markets that are segmented by borders. There are a few reasons why the border might matter. Much of the pricing-to-market literature has emphasised that the mark-up may be different across locations and may vary with exchange rate changes. There might also be 
direct costs to crossing borders because of tariffs and other trade restrictions. In addition, there may be more homogeneity in relative productivity shocks for city pairs within the same country than for cross-border city pairs, so that, from equation (1), cross-border pairs have more price volatility. Another important reason why the border matters is unrelated to equation (1): the price of a consumer good might be sticky in terms of the currency of the country in which the good is sold. Goods sold in Germany might have sticky prices in German mark terms, and goods sold in Italy might have sticky prices in Italian lira terms, whilst the nominal exchange rate is highly variable. In this case, the cross-border prices would fluctuate along with the exchange rate, but the within-country prices would be fairly stable. To capture this effect, we include a border dummy variable, $B(j, k)$, that takes on a value of unity if cities $j$ and $k$ are in different countries. This border dummy is likely to capture both formal and informal international barriers to trade. We typically find the border-effect to be positive and significant.

\section{II.2.1. Regression Results for EMU}

\section{II.2.1.1. Cross-Country Regressions for the Overall Sample}

Table 2a summarises our estimation results for the two specifications (1) and (2) and four different volatility measures during overall sample period (1995:I-2000:VI). The first column of Table $2 \mathrm{a}$ presents the results of regressing the variance of the 1-month change in the $\log$ relative price on $\log$ distance, 15 Borders, and 81 individual location dummies (one for each of our cities, not reported for convenience). All coefficients have the anticipated sign and are significant at least at the 5 percent level. The coefficient on the border dummies range between 1.59 (s.e. 0.035) for the German-Austrian Border to 13.6 (s.e. 0.13) for the Swiss-Portugese border, which is almost 10 times as large. The individual dummies for each border, of which there are $15(=6 * 5 / 2)$, all have the expected sign and are significant. The largest border effects are found for Switzerland. These positive and significant estimated border effects confirm the results documented by Engel and Rogers (1996, 2000): crossing an international border adds considerable volatility to

\footnotetext{
${ }^{6}$ For example, there may be trade barriers or marketing and distribution costs.
} 
relative city prices, even after accounting for the effects of distance and city-specific characteristics.

Table 2a also displays the results when the distance function is quadratic, rather than logarithmic. This is reported as specification 2, which is interesting because it allows a test for our assumption of a concave distance relationship. We find that distance has a significantly positive effect on price variability, whilst the square of distance has a significantly negative effect, as is postulated by a concave distance relationship. Again border dummy is positive and significant.

Like Engel and Rogers (1996, 2000) we also perform further robustness checks in which we employ a filtered measure of relative price volatility (measure 2) and the spread between the 10th and 90th percentiles (measure 3) as alternative measures of volatility. Table 2a shows that these modifications do not affect the key features of our results, which are essentially identical to the results reported above. We find that the coefficients on distance and the border dummy are highly significant and of the hypothesised sign.

Although we report White's (1980) heteroscedasticity-consistent standard errors, we also specifically allow for the possibility that the variance of the error term might be greater for more distant cities. The last specification in Table 2a reports results when the left- and right-hand-side variables are all deflated by the $\log$ of distance, so that the standard deviation of the regression error is modelled as being proportional to the log of distance between cities. The constant terms and the coefficients on the deflated border dummy are positive, as predicted, and highly significant in the regressions

What explains the relative sizes of these border effects? Nominal exchange rate variability is a prime candidate. Replacing the individual border dummies by one aggregate border dummy allows us to include in one regression specification both the border dummy and the variability of one-month nominal exchange rate changes, which of course is zero for all intra-national pairs. The results are reported in Table $2 \mathrm{~b}$. For our overall sample the coefficient on nominal exchange rate variability is 0.249 . Including nominal exchange rate variability substantially weakens the effect of the border dummy, whose point estimate falls from 301.8 to 1.44 . This suggests that a very large part of the border effect is from variable nominal exchange rates under sticky prices. However, even with $V(\Delta s(j, k))$ in the 
regression, the border dummy remains positive and significant with a t-statistic exceeding 15. Figure 1 explains why this is the case: for some countries in our sample there is no obvious relationship between the variance of nominal exchange rates and relative prices. For Spain, Portugal and Switzerland both variables move one-to-one, but for Italy relative prices volatility relative to the other countries is much smaller than exchange rate volatility. This fact is picked up by the significant aggregate border dummy.

What impact is EMU likely to have on the importance of borders? Will national borders still matter in EMU? In order to analyse the impact of the elimination of exchange rate volatility on the significance of European borders we now turn to the analysis of the sub-periods.

\section{II.2.1.2. Cross-Country Regressions for the ERM and EMU Sub-Periods}

The results reported so far were computed for the full sample period, 1995:12000:6. Table 3 presents summary statistics for two different sub-periods: 1995:1-98:12 and 1999:1-2000:6. The sub-periods correspond to the late ERM and early EMU subsamples. The first period includes the aftermath of the foreign exchange market turbulence during the ERM crisis (1992:9-93:7), when major exchange rate movements took place and Italy withdrew temporarily from the ERM. We notice several characteristics of the data: first, intra-national (within-country) relative price volatility is low prior to EMU (1995-98) and does not decline significantly during EMU (1999-2000). Second, international relative price volatility is high prior to EMU (1995-98) and particularly pronounced between the Southern European periphery (Italy, Spain, Portugal) relative to the North European core countries (Germany and Austria). An intermediate volatility cluster is found for all bilateral combinations involving Switzerland. Third, inter-national relative price volatility fell drastically for all EU cross-border city pairs due to the elimination of exchange rate variability. For example, price volatility fell from 10.2 to 2.7 for German-Italian city pairs, whilst it only was reduced from 4.3 to 3.5 for GermanAustrian city pairs. The EMU effect has therefore been particularly strong for formerly quite volatile Southern European exchange rates, whilst for relatively stable exchange rates there has only been a minor effect. Finally, in addition to the strong decreased of inter- 
national relative price volatility within the EU, the data also reveal a sizeable reduction in relative price volatility between Switzerland and the EU. This convergence process may be due to a deliberate policy of shadow-targeting the Euro exchange rate by the Swiss National Bank.

Figure 3 displays the variability of relative price changes for the two sub-periods. Whilst all intra-national city pairs experience no major change in volatility, the international volatility declines sharply. ${ }^{7}$ Figure 4 takes a closer look at all 3240 cross-city volatility measures in both the pre-EMU (panel a) and EMU sample (panel b). The scale of both graphs is chosen to be the same, so that the reduction of relative price volatility for all cross-border city pairs is more directly visible. In panel (b) of Figure 4 it is impossible to discriminate visually between within-country and within-EU relative price volatility, whereas the EU-Swiss city pairs is still clearly identifiable as having a higher volatility. As a first approximation one may therefore be tempted to conclude that EMU has eliminated inter-national differences in relative price volatility between EU cities. The formal analysis below will show that this conclusion is not valid, and that national borders continue to matter for relative price volatility even in EMU.

Table 3 displays the estimates of equations (1) and (2) for the overall period and for the two sub-periods. In equation (1) the regression coefficient on log distance is significant in the first sub-sample, but insignificant in the second sub-sample. This may be due to the functional form chosen. Using the linear-quadratic specification from equation (2) we find that both distance and distance squared are significant with the right sign in both subsamples. We therefore conclude that even in EMU distance matters for price volatility. ${ }^{8} \mathrm{~A}$ second interesting feature of Table 3 is the significance of all broader dummies in both the pre-EMU and EMU sample. We find sizeable and significant border effects for all countrypairs. The most drastic reduction (by roughly 80 percent) in the estimated border effects is found for EMU countries, in particular for the Southern European periphery (Italy, Spain, Portugal) relative to the Northern European core-countries (Germany and Austria), and

\footnotetext{
${ }^{7}$ Engel and Rogers (2000) find a sizeable reduction in intra-national relative price volatility in an earlier sample, and attribute this decline to an increased economic integration within countries, which is likely to be caused by advancements in transportation, communication, etc.

${ }^{8}$ Note that the more robust specification (2) was also used in Engel and Rogers (2000), who also conclude that distance matters for price volatility. We show that this result also applies for EMU: the further two EU cities are apart, the higher will be the degree to which relative price changes can occur.
} 
intra-EU border effects do not differ significantly in the EMU sample. An intermediate border effect is found for all bilateral combinations involving Switzerland, which is more than 3 times as large as the within-EU border effect.

To summarise, the shift in the variance of the nominal exchange rate from the ERM to the EMU sample can be interpreted as an exogenous event, as part of a political process that ultimately led to European Monetary Unification. Relative price volatility has fallen as a result of the decline in the nominal exchange rate variance. We find that during EMU distance is notably smaller and insignificant. The estimated border coefficients are still positive and significant, but are less one-fifth of their size in the pre-EMU sample. This suggests that a common monetary policy leads to greater market integration of regions within countries and between countries.

\section{II.2.1.1. Cross-Country Regressions for Dis-aggregate CPI Components}

One of the major advantages of our data set is that we can the calculate relative price volatility measures not only for the aggregate CPI, but also for 7 dis-aggregate gategories of CPI components. In Table $4 \mathrm{a}$ to $4 \mathrm{~d}$ we display these results for our volatility measure 1 in the overall period as well as for the pre-EMU and EMU sub-samples. The general pattern of the results is the same as in Table 3: In each category except education our regressions identify as significant link between relative price volatility and distance. For the overall period the distance coefficient is largest for health $(0.55)$, followed by clothing (0.47), fuel (0.27) food (0.23), transportation (0.15), and furniture (0.12). Distance coefficients for the CPI components do not change a drastically across sub-samples, but frequently are insignificant in the second sub-sample (for health, furniture, fuel and education).

The border coefficients for the dis-aggregate CPI components also mirror the pattern of the estimates for the overall CPI. Due to missing data we only include Switzerland in the regressions for food, fuel and transportation, where again the largest border effects are found for this country relative to EU locations. All border effects are highly significant in the first sub-sample. In the second sub-sample (EMU) only the border 
dummy for Italy and Spain relative to Germany becomes insignificant for clothing, whilst all others remain significant at a generally lower value. As for aggregate CPI, the reduction of the border effects between the two sub-samples is most pronounced between the coreEU countries and the Southern periphery.

To summarise, the results from this dis-aggregated data suggest that our conclusions from the preceding sections are largely robust. The variance in relative goods prices is closely related to the variance of nominal exchange rates.

\section{II.2.2. Regression Results for GEMU}

The above results for EMU were obtained for a relatively small sample (19952000) and the 18-months of data from the EMU sub-period reveal only a limited amount of information about the long-run effects of the monetary union on within-EMU relative price dispersion. In particular, we are unable to obtain formal evidence about the speed of relative price convergence amongst European cities because estimating dynamic time series models on such few data points is unlikely to yield reliable results about these longrun effects.

An interesting feature of our data set is that it contains West and East German data for the entire 10-year period of German Economic and Monetary Union (GEMU). Can we learn anything about the long-run dynamic effects of EMU on relative price dispersion from the German experience? In order to find out, we estimated all our regressions from above also for this longer 1991-2000 sample. As a control group we added Austrian and Swiss cities to the sample. We think that analysing such a homogeneous sample of adjacent countries with a common language and long-standing political, cultural and economic linkages will provide an estimate for the upper bound of the speed of convergence we may realistically expect from EMU. To estimate the direct effects of GEMU on East-West German integration we include a shadow-border in the form of a East-West German border dummy in all regressions. 


\section{II.2.2.1. Cross-Country Regressions for GEMU}

Table 5 displays the estimates of equations (1) with volatility measures 1 and 2 for the overall GEMU period (1991:1-2000:6) and for three GEMU sub-periods (1991:11994:12, 1995:1-1998:12, 1999:1-2000:6). In equation (1) the regression coefficient on log distance is significant in the overall period and the first and second sub-sample, but insignificant in the third sub-sample. A second feature of Table 5 is the significance of the East-West broader dummy in the overall period and both pre-EMU samples. Thus, even after the start of monetary union in Germany there was a significantly different pattern of relative price changes amongst cities within each part of Germany as compared to cities located across the former "iron curtain." This is most likely the result of slow price deregulations and a gradual unlocking of formerly administered prices for housing, rent and certain goods in East Germany. By 1999 much of this price de-regulation between East and West Germany appears to have been completed and the shadow-border is no longer significant. An interesting characteristic of our results for the immediate post-unification period is that our measure of economic integration suggests that West Germany, Austria and Switzerland were by far more integrated with each other than with East Germany. Integration of East and West Germany proceeded speedily during 1995-1998, when the East-West German border effect fell by over 90 percent from 18.4 to 0.5 , as compared to the minor reduction of the German-Austrian border effect from 2.6 to 2.3 for the same period. By this metric, the two parts of Germany became four times more integrated during the 1990s than Germany and Austria did in spite of long history of virtually no exchange rate volatility between the two countries.

\section{II.2.2.2. Time Series Evidence for GEMU}

In the above analysis we have identified an EMU-effect that is equal to an 80 percent reduction in intra-EMU relative price volatility for core-Europe relative to the Southern periphery and in our GEMU sample we even found a reduction of intra-German relative price volatility that exceeded 90 percent. Both monetary unions therefore resulted in impressive integration effects. Like in the convergence regressions popularised in the growth literature, a low initial degree of economic integration thereby appears to 
succeeded by a more rapid convergence progress. In order to examine this proposition more formally, the following analysis makes explicit use of the time series dimension of the data.

Instead of running a cross-section regression with $528\left(=33^{*}(32 / 2)\right)$ city pairs for the German-Austrian-Swiss sample we constructed 528 time series of one-month relative price (real exchange rate) changes between our 528 city pairs. For each of these time series we then ran an Augmented Dickey Fuller unit-root test for the overall sample (1991:12000:6) by regressing the change of the real exchange rate on its past level and one lagged difference term. Instead of reporting here the 528 AR(1) coefficients Figure 6 displays the Kernel density estimates of these AR(1) coefficients for the various intra-national and inter-national city pairs. Within-country $\mathrm{AR}(1)$ coefficients are typically quite dispersed and skewed towards unity. The lowest $\mathrm{AR}(1)$ coefficients and hence the highest convergence speeds are found between Austria and Germany and within Austria. All AR(1) coefficient estimates relative to East Germany have a very narrow density distribution, typically around a mean value of 0.9. The upper part of Table 5 summarises these coefficient estimates. The half-lives implied by these coefficients are between 6 and 19 months. The estimated speed of convergence is particularly low within countries (Germany, Switzerland). Since relative price volatility was found to be the smallest within countries too, we conclude from this that most price convergence within countries has already been achieved in the past and that a further convergence is unlikely. The opposite result holds for East Germany, which faced quite different initial relative price movements and hence displayed the largest speed of relative price convergence.

\section{II.2.2.3. Panel Evidence for GEMU}

A major problem with the above evidence is that averaging over a large number of independently estimated AR(1)-coefficients may only yield a very imprecise picture of the convergence properties of relative prices within a monetary union. Furthermore, with only 10 years of data the power of such ADF-based tests in discriminating an AR(1)-coefficient close to unity from a unit root is known to be low. Pooling the cross-section data and performing a panel unit root test has been shown by Levin and Lin (1992), Oh (1993) and 
$\mathrm{Wu}$ (1993) to considerably increasing the power of such a tests. In this section we will briefly discuss the convergence properties of relative prices in Europe found by running panel unit root tests.

To conduct the panel-based test, for each panel of relative prices (real exchange rates), $P_{j k, t-1}$, the raw data are first transformed by subtracting the individual-specific mean and the time-specific mean. Let $\tilde{P}_{j k, t-1}$ denote the transformed relative prices. In order to correct for possible serial correlation we employ the ADF method, and the estimation equation employed is given by:

$$
\Delta \tilde{P}_{j k, t}=b \tilde{P}_{j k, t-1}+\sum_{i=1}^{p} \phi_{i} \Delta \tilde{P}_{j k, t-i}+\tilde{\varepsilon}_{j k, t}
$$

We do not pool all the 528 individual time series in one regression equations since we belief that such a unique speed of relative price convergence across all city pairs would be rather meaningless. However, the lower part of Table 6 summarises the panel estimates of the intra-national and inter-national convergence speeds based on the panel unit root test developed by Levin and Lin (1992) and Wu (1993). Note that we include a shadow East-West German border to study the convergence speed of relative prices between cities located in the two formerly separated parts of Germany. The panel-based estimates of convergence speeds turn out to be much lower. Within West Germany we find a half-life of roughly 10 years, whilst East-West relative prices converged with a half-life of only 10 months. Convergence within East German was even faster at only 5 months half-life. Finally, between the West German cities and Austrian or Swiss cities we find an intermediate relative price convergence with a half-life of 2 to 4 years. These last numbers roughly correspond to the evidence about the slow speed of real exchange rate convergence between industrialized countries reported in the introduction of the present paper.

Our estimates of a slow rate of relative price convergence within a country is consistent with similar estimates provided by Cecchetti, Mark and Sonora (1999) for the U.S. economy. They study price level convergence among U.S. cities and find that relative price levels mean revert, but at a surprisingly slow rate. In a panel of 19 cities they 
estimate the half-life of convergence to be approximately 9 years. We find a very similar number for West Germany, but much lower numbers for all other city pairs. Cecchetti, Mark and Sonora (1999) conclude that their estimates for the U.S. provide an upper bound on speed of convergence that participants in the European Monetary Union are likely to experience. However, our results indicate a much larger speed of convergence in European price level dispersion. We therefore disagree with the conclusion of Cecchetti, Mark and Sonora (1999) and view the U.S. evidence as provide a lower rather than an upper bound for European speeds of relative price convergence. 


\section{Conclusions}

The major message of our empirical results is that the elimination of nominal exchange rate volatility in a monetary union will give a major boost to economic integration by significantly reducing cross-border relative price volatility. However, moving to a common currency neither immediately nor in the long-run completely eliminate cross-country relative price volatility. Even in a monetary union national borders and distance continue to be important determinants of relative price volatility. Looking at both the German unification experience and the early phase of European Monetary Union we are able to establish that relative price convergence is likely to occur drastically within a matter of a few month rather than years. The half-life of the East-West German price level convergence is estimated around 5 month. The convergence dynamics between Germany and Austria during the 1990s under a virtually fixed exchange rate lie around 2 to 3 years. We expect similar convergence speeds for the remaining European countries. Our preliminary evidence for the first 18 months of EMU suggests that price level convergence has already occurred to a large extend and that roughly 90 percent of the initial relative price dispersion is by now eliminated.

The literature on pricing to market has emphasised that, when markets are segmented, price discrimination can occur. The finding that distance is important in explaining price differences between locations in Europe lends support to this literature. EMU is found to have greatly reduced but not completely eliminated the importance of intra-EU borders. Our width-of-the-border metric suggests that due to EMU European locations have grown closer together. However, the results of this paper also confirm the Engel and Rogers (2000) finding that despite more price transparency under a common 
monetary policy and the complete absence of the intra-EU trade barriers, European product markets are still segmented.

\section{Data Appendix}

Our data are described in detail in Appendix Table A1. All of the price data (for all countries) are seasonally unadjusted. We use comparable price data for the aggregate CPI and for 8 dis-aggregate components of goods prices in six European countries (Germany, Austria, Switzerland, Italy, Spain and Portugal). The composition and weights of these series is documented in rows 2-8 of Table A1. All these categories of goods are mutually exclusive. Together they comprise a large fraction of the overall CPI.

Monthly price data were used for 12 German cities (Capital of Länder), 20 Austrian cities, 4 Swiss cities, 20 Italian cities, 18 Spanish cities and 7 Portugese cities. Consumer price data are closer to being monthly average data than point-in-time data. In order to compare prices internationally we use a monthly average exchange rates from the IMF (International Financial Statistics). For each good, we calculated the inter-city relative prices.

We also use data on the distance between cities. We use a measures of distance obtained from the ???? software. Our distance measure is the great-circle distance. 


\section{References}

Abuaf, N. and P. Jorion, 1990. Purchasing power parity in the long run. Journal of Finance $45,157-174$.

Beck, G. and A.A. Weber, 2001a, How wide is the Pacific?, mimeo.

Cecchetti, S.G., C.M. Nelson and R. Sonora, 1999, ,Price Level Convergence Among United States Cities: Lessons for the European Central Bank," mimeo.

Dornbusch, R., 1987, Exchange Rates and Prices, American Economic Review 77, 93-106.

Dumas, B., 1992, Dynamic Equilibrium and the Real Exchange Rate in a Spatially Separated World, Review of Financial Studies, 153-180.

Edison, H.J., J.E. Gagnon, and W.R. Melick, 1997. Understanding the empirical literature on purchasing power parity: the post-Bretton Woods era. Journal of International Money and Finance 16, 1-17.

Engel, C., 1993. Real exchange rates and relative prices: an empirical investigation. Journal of Monetary Economics 32, 35-50.

Engel, C., 1999. Accounting for U.S. real exchange rate changes. Journal of Political Economy, forthcoming.

Engel, C. and J.H. Rogers, 1996, „How Wide Is the Border?“"American Economic Review $86,1112-1125$.

Engel, C., M.K. Hendrickson, and J.H. Rogers, 1997. Intra-national, intra-continental and intra-planetary PPP. Journal of the Japanese and International Economies 11, 480501.

Engel, C. and J.H. Rogers, 1998, Regional patterns in the law of one price: The roles of geography versus currencies, in, Jeffrey A. Frankel, ed., The regionalization of the world economy (Chicago: University of Chicago Press.)

Engel, C. and J.H. Rogers, 2000, Deviations from purchasing power parity: causes and welfare consequences, Journal of International Economics, forthcoming.

Frankel, J.A. and A. Rose, 1996. A panel project on purchasing power parity: mean reversion within countries and between countries. Journal of International Economics 40, 209-224.

Frankel, J.; E. Stein and W. Shang-Jin, 1995, "Trading Blocs and the Americas: The Natural, the Unnatural and the Super-natural.' Journal of Development Economics 67, 61-96.

Froot, K.A. and P.D. Klemperer, 1989, Exchange Rate Pass-Through when Market Share Matters, American Economic Review 79, 637-54.

Goldberg, P.K. and M.M. Knetter, 1997, Goods prices and exchange rates: What have we learned, Journal of Economic Literature 35, 1243-1272.

Helliwell, J., 1996, Do national borders matter for Quebec's trade?, Canadian Journal of Economics 29, 507-522.

Helliwell, J., 1998, How much do national borders matter?, manuscript.

Isard, P., 1977, How Far Can We Push the Law of One Price?, American Economic Review 67, 942-48.

Knetter, M.N., 1989, Price Discrimination by U.S. and German Exporters, American Economic Review 79, 198-210. 
Krugman, Paul, 1987, Pricing to market when the exchange rate changes, in Sven W. Arndt and J.David Richardson, eds., Real-financial linkages among open economies (Cambridge, MA.: MIT Press), 49-70.

Krugman, P., 1991, Geography and trade (Cambridge, MA.: MIT Press).

McCallum, J., 1995, National borders matter: regional trade patterns in North America, American Economic Review 85, 615-623.

Mussa, M., 1986, Nominal Exchange Rate Regimes and the Behavior of Real Exchange Rates: Evidence and Implications, Carnegie-Rochester Conference Series on Public Policy 25, 117-214.

Newey, W.K. and K.D. West, 1987. A simple positive semi-definite, heteroskdeasticity and autocorrleation consistent covariance matrix. Econometrica 55, 703-708.

Obstfeld, M., 1997, Europe's gamble, Brookings Papers on Economic Activity, no. 2, 241317.

Obstfeld, M. and A. Taylor, 1997. Nonlinear aspects of goods-market arbitrage and adjustment: Heckscher's commodity points revisited. Journal of the Japanese and International Economies 11, 441-478.

O'Connell, P., 1998. The overvaluation of purchasing power parity. Journal of International Economics 44, 1-19.

O'Connell, P.J. and S.-J. Wei, 1997, The bigger they are, the harder they fall: How price differences across cities are arbitraged, National Bureau of Economic Research, working paper no. 6089.

Parsley, D. and S.-J. Wei, 1996, Convergence to the law of one price without trade barriers or currency fluctuations, Quarterly Journal of Economics 111, 1211-1236.

Parsley, D. and S.-J. Wei, 2000, Border, border, wide and far, how we wonder what you are, Journal of International Economics, forthcoming.

Rogoff, K., 1996, The purchasing power parity puzzle, Journal of Economic Literature 34, 647-668.

Rogers, J.H., 1999, Monetary shocks and real exchange rates, Journal of International Economics 49, 269-288.

Rogers, J.H. and M. Jenkins, 1995, Haircuts or hysteresis? Sources of movements in real exchange rates, Journal of International Economics 38, 339-360.

Rogers, J.H, G.C. Hufbauer and E. Wada, 2001, Price Level Convergence and Inflation in Europe, Institute for International Economics Working Paper No. 01-1.

Wei, S.-J. and D.C. Parsley, 1995. Purchasing power disparity during the floating rate period: exchange rate volatility, trade barriers and other culprits. National Bureau of Economic Research, working paper No. 5032.

Wei, S.-J., 1996, Intra-national versus inter-national trade, National Bureau of Economic Research, working paper no. 5531.

Wolf, H., 1997, Patterns of intra- and inter-state trade, National Bureau of Economic Research, working paper no. 5939.

White, H., 1980, A Heteroskedasticity-Consistent Covariance Matrix Estimator and a Direct Test for Heteroskedasticity, Econometrica 48, 817-38. 
Figure 1: The Variances of Average Relative Price Changes and Nominal Exchange Rate Changes, Overall Period (1995:1-2000:6)

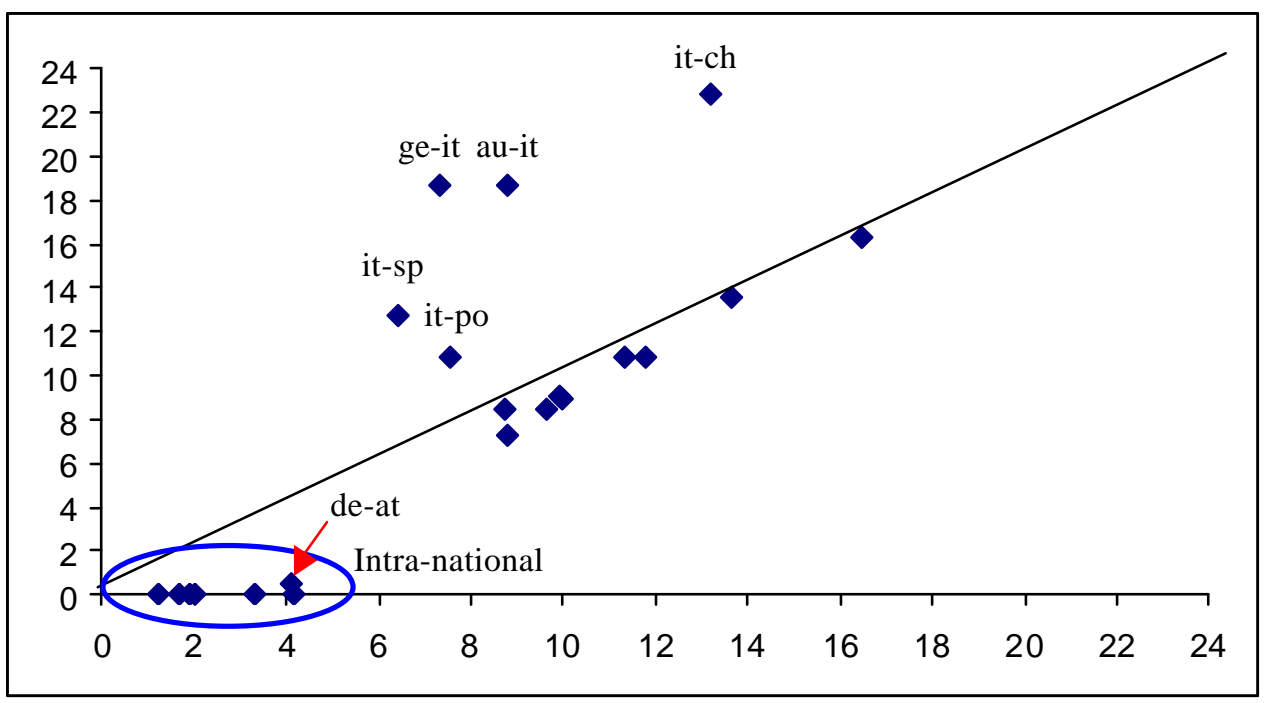

Key to Figure: The variance of nominal exchange rate changes is plotted on the vertical axis, and the variance of average relative price changes (across locations) are on the horizontal axis. 


\section{Figure 2:}

Cross-city Relative Price Volatility, Overall Sample, Jan. 1995- Dec. 1998

Date: Sun Jan 28 13:53:37 2001

Std.dvt. against Distance (Grouped)

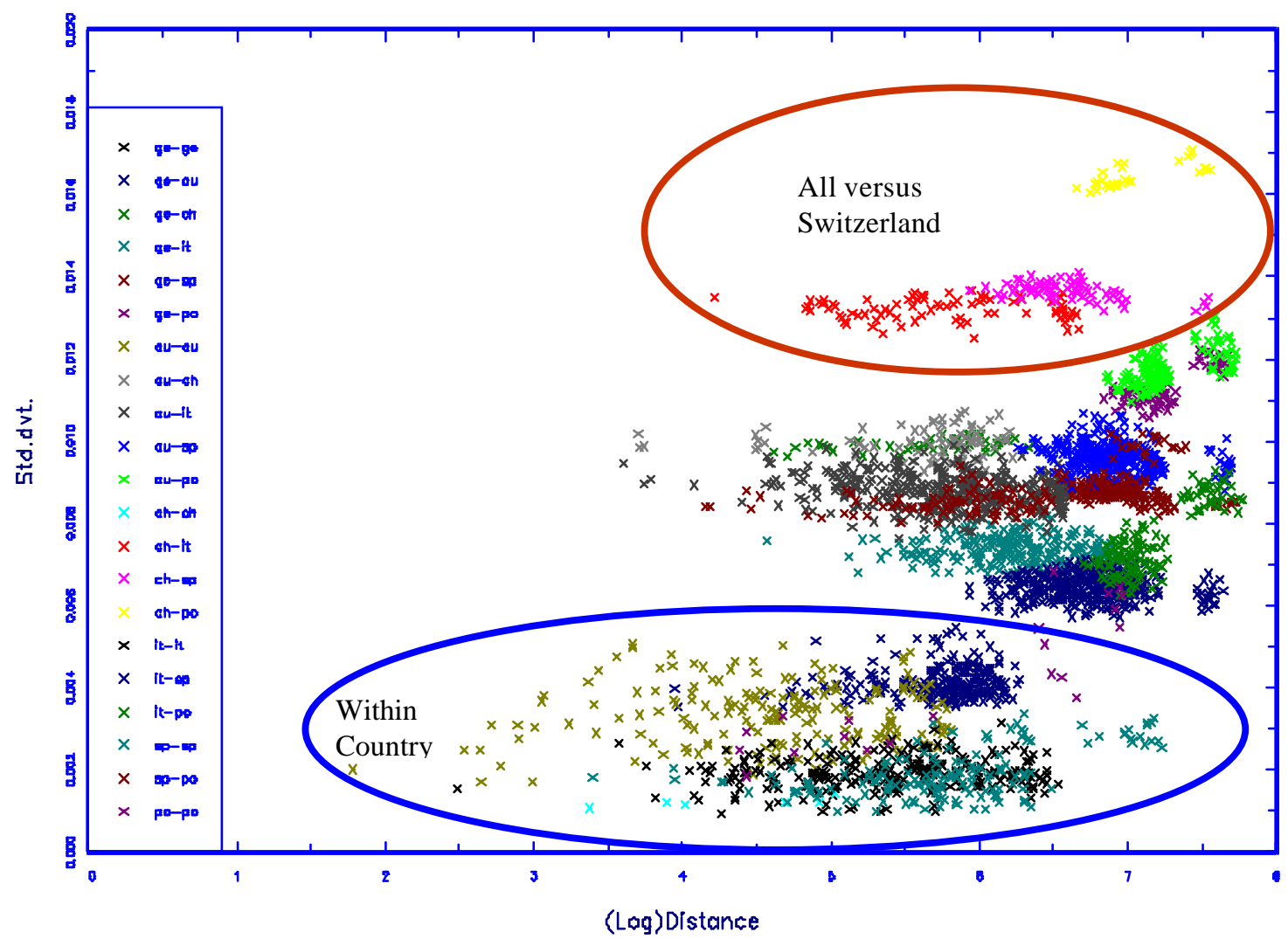


Figure 3: Volatility of Relative Price Changes in the ERM (1995:1-1998:12) and EMU (1999:1-2000:6) Periods,

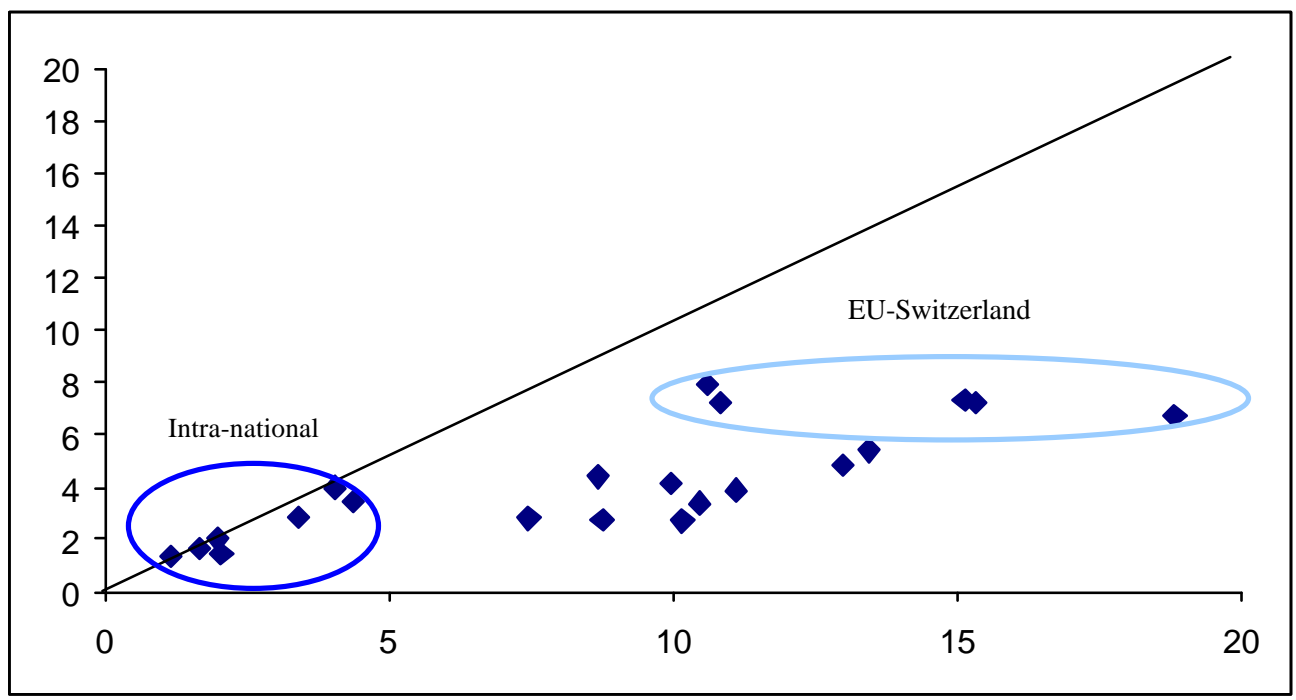

Key to Figure: EMU Sub-Period (1999:1-2000:6) on the vertical axis, pre-EMU sub-period on the horizontal axis. 
Figure 4:

(a) Cross-city Relative Price Volatility, Pre-EMU, Jan. 1995- Dec. 1998

Date: Man Jan 22 11:0B:12 2001

Std.dvt. against Distance (Grouped)

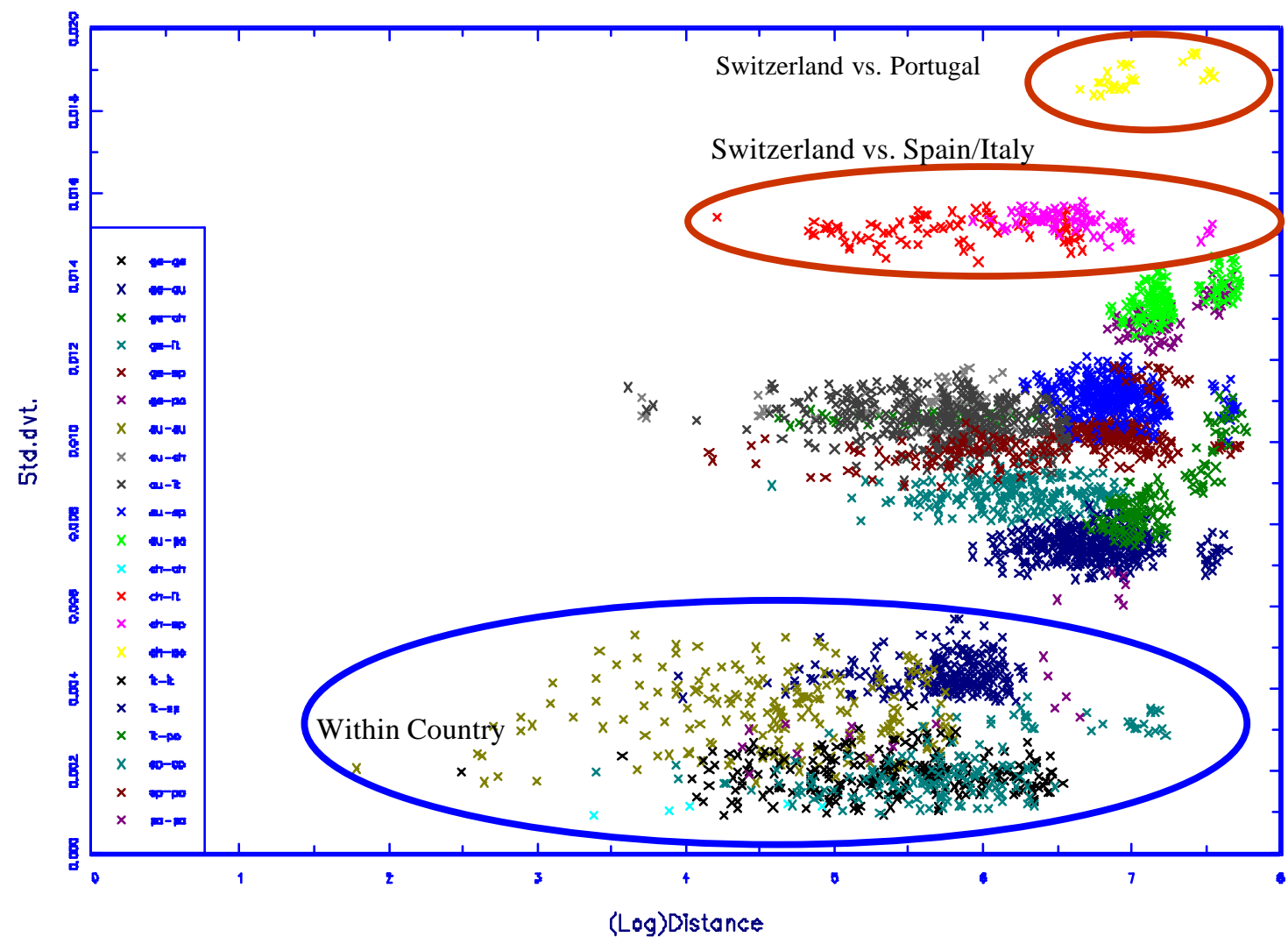

(b) Cross-city Relative Price Volatility, EMU, Jan. 1999- June 2000

Date: Tue Jon 23 00:26:11 2001

Std.dvt. against Distance (Grouped)

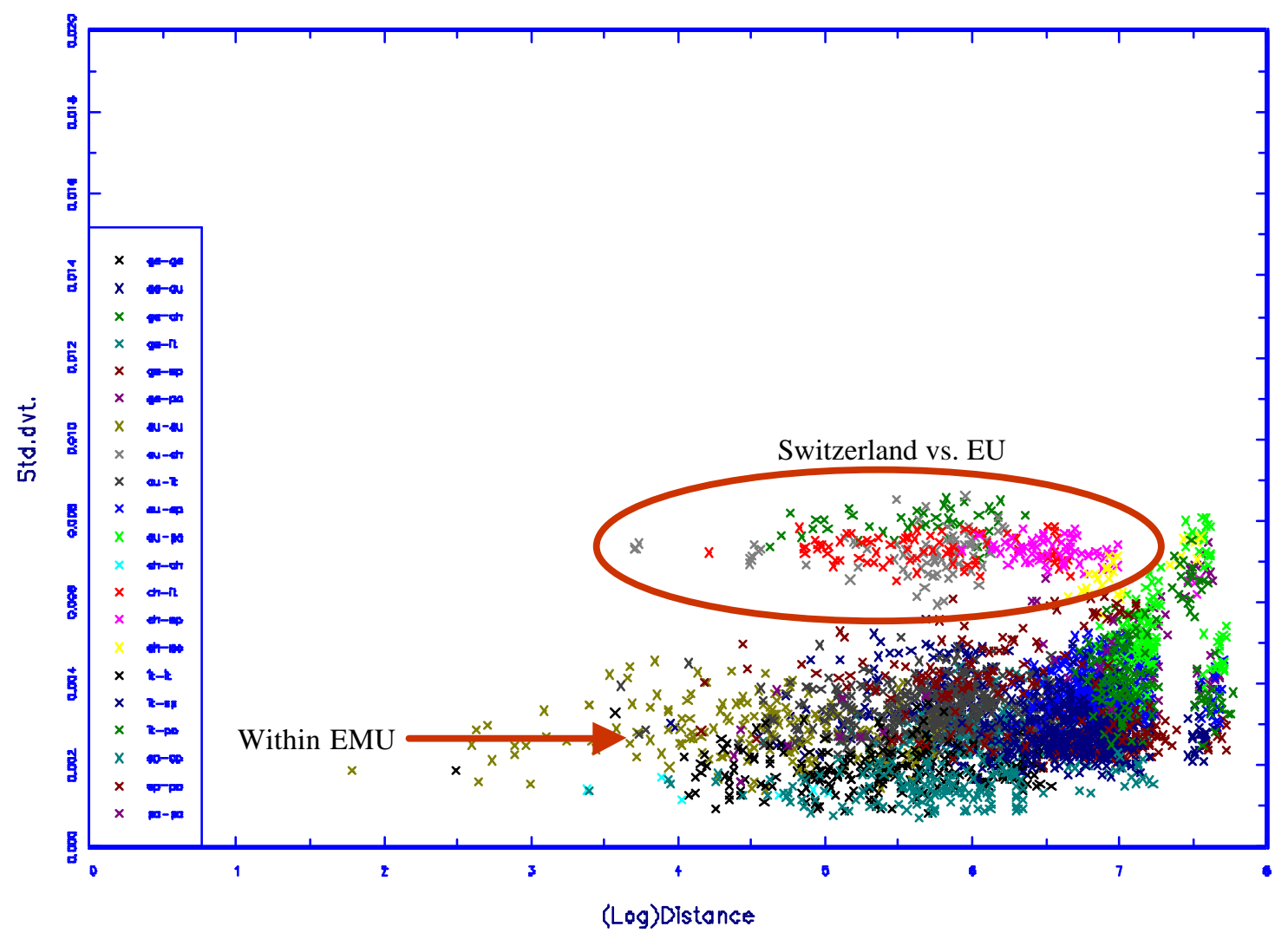


Figure 5

Kernel Density Estimates of AR(1) Cefficients for Real Exchange Rates of City Pairs within and between Countries
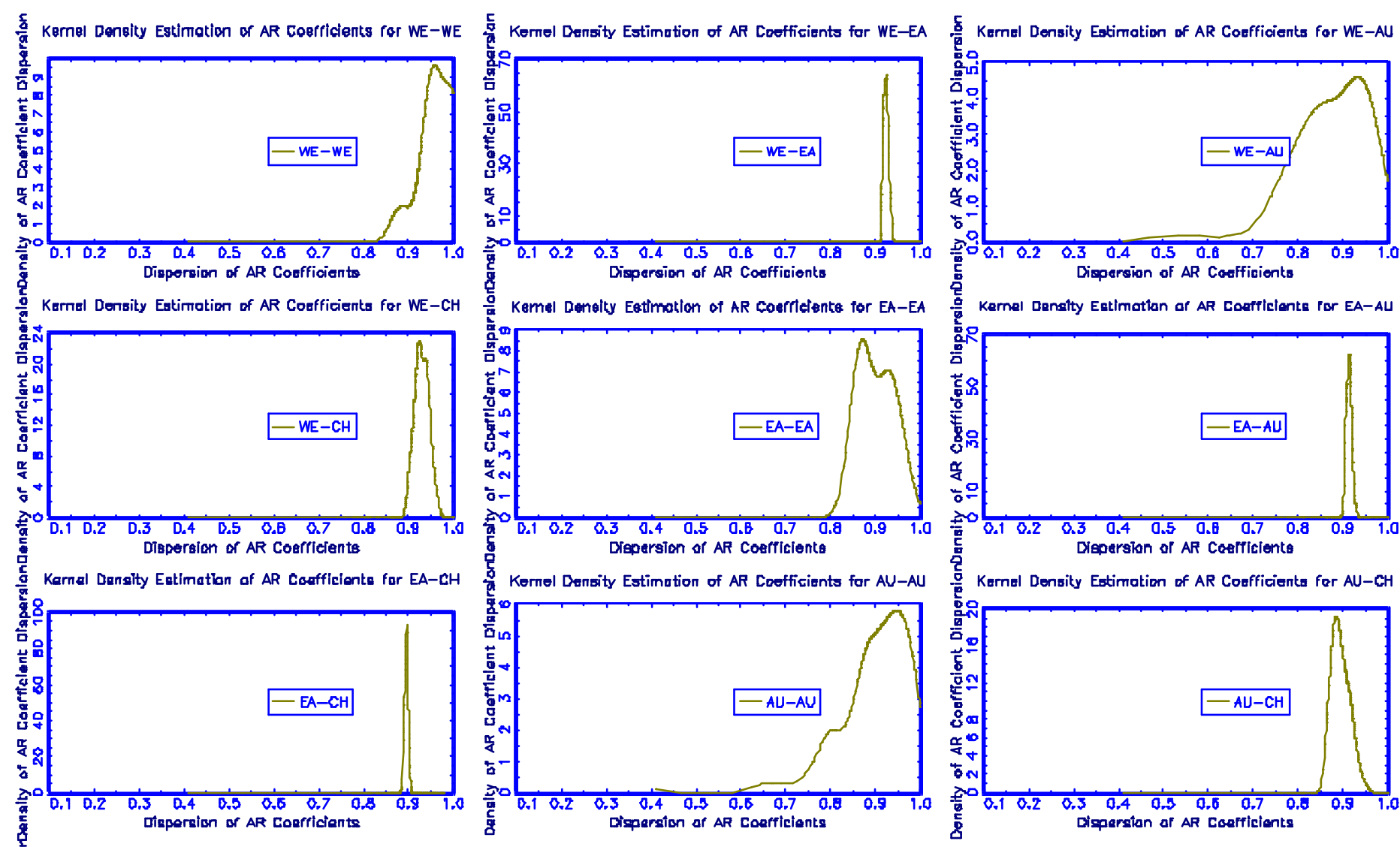

Kernel Density Eatimation of AR Coefficienta for $\mathrm{CH}-\mathrm{CH}$

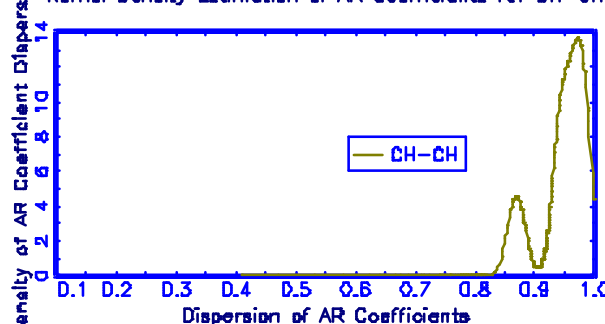

Note: AR(1) coefficients are obtained by regressing the change of the real exchange rate on its past level and one lagged difference term. The Kernel density estimates reported here are based on the $528 \mathrm{AR}(1)$ coefficients that result from these regressions 
Table 1:

Descriptive Statistics, Relative Price Volatility and Distance, Measure 1

Relative Locations, Indicated by Country Names

\begin{tabular}{|c|c|c|c|c|c|c|c|c|c|c|c|c|c|c|c|c|c|c|c|c|c|}
\hline Index & ge-ge & ge-au & ge-ch & ge-it & ge-sp & ge-po & $\mathrm{au}-\mathrm{au}$ & au-ch & au-it & au-sp & au-po & ch-ch & ch-it & ch-sp & ch-po & it-it & it-sp & it-po & sp-sp & sp-po & po-po \\
\hline & (1) & $(2)$ & $(3)$ & (4) & $(5)$ & $(6)$ & $(7)$ & $(8)$ & (9) & $(10)$ & $(11)$ & (12) & (13) & (14) & $(15)$ & (16) & (17) & (18) & (19) & $(20)$ & $(21)$ \\
\hline All Items, & & & & & & & & & & & & & & & & & & & & & \\
\hline Mean & 1,66 & 4,13 & 9,92 & 7,35 & 8,74 & 11,32 & 3,31 & 9,97 & 8,78 & 9,64 & 11,77 & 1,22 & 13,21 & 13,66 & 16,46 & 2,01 & 6,44 & 7,56 & 1,92 & 8,80 & 4,17 \\
\hline$S t d v$ & 0,37 & 0,38 & 0,13 & 0,31 & 0,18 & 0,43 & 0,74 & 0,35 & 0,41 & 0,32 & 0,44 & 0,12 & 0,26 & 0,21 & 0,29 & 0,34 & 0,30 & 0,81 & 0,59 & 0,55 & 1,59 \\
\hline Food, & & & & & & & & & & & & & & & & & & & & & \\
\hline Mean & 2,78 & 6,46 & 11,57 & 8,65 & 10,87 & 12,54 & 6,08 & 11,59 & 9,74 & 11,54 & 13,15 & 4,88 & 14,37 & 15,67 & 17,75 & 3,75 & 8,94 & 10,23 & 5,18 & 11,06 & 7,99 \\
\hline$S t d v$ & 0,38 & 0,81 & 0,31 & 0,39 & 0,81 & 1,16 & 1,02 & 0,64 & 0,67 & 0,80 & 1,05 & 0,67 & 0,57 & 0,78 & 0,94 & 0,65 & 0,77 & 1,90 & 1,75 & 1,48 & 3,11 \\
\hline Clothing, & & & & & & & & & & & & & & & & & & & & & \\
\hline Mean & 4,68 & 17,87 & - & 8,60 & 9,68 & 30,84 & 25,29 & - & 20,44 & 20,71 & 36,57 & - & - & - & - & 3,87 & 6,77 & 32,52 & 2,35 & 29,77 & 27,26 \\
\hline$S t d v$ & 3,05 & 12,65 & - & 1,81 & 1,50 & 10,98 & 12,69 & - & 13,21 & 11,93 & 11,57 & - & - & - & - & 1,27 & 0,72 & 12,88 & 0,99 & 11,34 & 13,67 \\
\hline Furniture, & & & & & & & & & & & & & & & & & & & & & \\
\hline Mean & 1,64 & - & - & 7,89 & 9,04 & 11,59 & - & - & - & - & - & - & - & - & - & 4,05 & 7,13 & 8,38 & 3,25 & 9,04 & 5,87 \\
\hline$S t d v$ & 0,60 & - & - & 1,03 & 0,61 & 0,66 & - & - & - & - & - & - & - & - & - & 1,83 & 1,06 & 1,14 & 1,14 & 0,92 & 1,48 \\
\hline Fuel, & & & & & & & & & & & & & & & & & & & & & \\
\hline Mean & 4,63 & - & 10,68 & 9,71 & 10,23 & 12,80 & - & - & - & - & - & 2,66 & 15,07 & 14,17 & 17,02 & 6,59 & 9,60 & 10,49 & 5,14 & 10,86 & 6,32 \\
\hline$S t d v$ & 1,70 & - & 0,76 & 1,41 & 1,50 & 1,01 & 1,50 & 1,01 & 1,50 & 1,01 & 1,50 & 0,60 & 1,14 & 1,15 & 0,66 & 1,76 & 1,65 & 1,57 & 2,61 & 1,49 & 2,68 \\
\hline Health, & & & & & & & & & & & & & & & & & & & & & \\
\hline Mean & 9,48 & - & - & 20,80 & 20,63 & 22,09 & - & - & - & - & - & - & - & - & - & 4,62 & 7,75 & 9,34 & 4,29 & 9,83 & 6,34 \\
\hline$S t d v$ & 4,92 & 1,18 & - & 6,35 & 5,67 & 5,41 & - & - & - & - & - & - & - & - & - & 2,02 & 1,11 & 1,49 & 1,01 & 1,15 & 1,48 \\
\hline Transport, & & & & & & & & & & & & & & & & & & & & & \\
\hline Mean & 3.61 & 6.39 & 11.36 & 8.82 & 10.00 & 13.65 & 4.29 & 11.25 & 8.26 & 9.59 & 11.85 & 2.03 & 12.85 & 14.36 & 17.15 & 3.54 & 7.60 & 9.09 & 2.17 & 10.16 & 6.19 \\
\hline$S t d v$ & 0.75 & 0.58 & 0.28 & 0.62 & 0.39 & 0.94 & 0.87 & 0.30 & 0.60 & 0.49 & 1.17 & 0.45 & 0.48 & 0.33 & 0.74 & 1.30 & 0.81 & 1.88 & 1.12 & 1.12 & 3.19 \\
\hline Educa & & & & & & & & & & & & & & & & & & & & & \\
\hline Mean & 3.08 & 20.55 & - & 15.60 & 16.75 & 18.47 & 4.78 & - & 23.08 & 26.50 & 26.71 & - & - & - & - & 6.50 & 8.50 & 10.19 & 4.84 & 11.15 & 9.65 \\
\hline$S t d v$ & 0.66 & 1.18 & - & 1.63 & 0.73 & 1.54 & 4.43 & - & 2.24 & 1.16 & 2.77 & - & - & - & - & 3.22 & 1.84 & 2.07 & 1.65 & 1.46 & 2.05 \\
\hline Exrate Var. & - & 0.49 & 9.08 & 18.68 & 8.44 & 10.89 & - & 8.98 & 18.67 & 8.42 & 10.88 & - & 22.86 & 13.56 & 16.27 & - & 12.72 & 10.91 & - & 7.32 & - \\
\hline Distance & 176 & 309 & 289 & 519 & 1.010 & 1.409 & 103 & 271 & 317 & 1.000 & 1.438 & 75 & 308 & 729 & 1.150 & 230 & 847 & 1.294 & 321 & 477 & 348 \\
\hline
\end{tabular}

Notes:1) Standard deviations are computed over the sample period from January 1995 to June 2000 (Exceptions: Italian Data are available from January 1996 only, Swiss Data end in May 2000).

2) The number of available observations per category are (number of cities in brackets): All Items: 3240 (82 cities), Food: 3081 (81 cities), Clothing: 2926 (77), Furniture: 1596 (57), Fuel: 1770 (60), Health: 1596 (57), Transport: 3160 (80), Education: 2850 (76) 
Table 2a: All Items

Estimation Using Log Distance Function, Overall Period (Jan 1995-June _2000), Volatility Measures 1, 2, 3 and 4

\begin{tabular}{|c|c|c|c|c|c|c|c|c|c|c|c|c|}
\hline \multirow[b]{2}{*}{ Variable } & \multirow[b]{2}{*}{ Coeff. } & \multicolumn{3}{|c|}{ Measure 1} & \multirow[b]{2}{*}{ Stde. } & \multirow[b]{2}{*}{ t-stat. } & \multicolumn{2}{|c|}{ Measure 2} & \multicolumn{2}{|c|}{ Measure 3} & \multicolumn{2}{|c|}{ Measure 4} \\
\hline & & Stde. & t-stat. & Coeff. & & & Coeff. & Stde. & t-stat. & Coeff. & Stde. & t-stat. \\
\hline Constant & & & & & & & & & & & 0,11 & 0,03 \\
\hline $\log ($ Distance $)$ & 0,065 & 0,022 & 3,03 & & & & 0,154 & 0,056 & 0,071 & 0,022 & & \\
\hline Distance sqr. & & & & $-0,400$ & 0,000 & $-9,95$ & & & & & & \\
\hline Border ge-au & 1,587 & 0,035 & 44,73 & 1,604 & 0,034 & 47,03 & 4,031 & 0,088 & 1,436 & 0,035 & 1,58 & 0,04 \\
\hline Border ge-sp & 6,858 & 0,046 & 148,75 & 7,044 & 0,052 & 136,10 & 9,353 & 0,124 & 5,071 & 0,047 & 6,836 & 0,058 \\
\hline Border ge-por & 8,292 & 0,118 & 70,25 & 8,718 & 0,112 & 77,62 & 8,787 & 0,297 & 6,831 & 0,129 & 8,353 & 0,113 \\
\hline Border au-ch & 7,637 & 0,060 & 127,32 & 7,662 & 0,060 & 128,31 & 17,569 & 0,215 & 7,334 & 0,070 & 7,632 & 0,061 \\
\hline Border au-it & 6,074 & 0,030 & 204,63 & 6,092 & 0,029 & 209,99 & 11,179 & 0,095 & 6,145 & 0,031 & 6,068 & 0,032 \\
\hline Border au-sp & 6,907 & 0,047 & 146,78 & 7,096 & 0,053 & 134,68 & 8,786 & 0,133 & 4,941 & 0,049 & 6,885 & 0,054 \\
\hline Border it-sp & 4,402 & 0,036 & 122,12 & 4,522 & 0,039 & 116,58 & 9,739 & 0,112 & 4,483 & 0,038 & 4,375 & 0,045 \\
\hline Border it-po & 4,367 & 0,115 & 37,95 & 4,727 & 0,107 & 44,30 & 10,466 & 0,285 & 4,122 & 0,128 & 4,403 & 0,108 \\
\hline Border sp-po & 5,730 & 0,110 & 52,12 & 5,765 & 0,091 & 63,67 & 6,773 & 0,271 & 4,814 & 0,120 & 5,876 & 0,094 \\
\hline $\mathrm{R}^{2}$ & 0.9915 & & & 0.9920 & & & 0.9655 & & 0.9854 & & & \\
\hline $\mathrm{R}^{2}$ (adj.) & 0.9912 & & & 0.9918 & & & 0.9644 & & 0.9849 & & & \\
\hline $\operatorname{SEE}(* 1000)$ & 0.3087 & & & 0.2989 & & & 0.1192 & & 0.3532 & & & \\
\hline
\end{tabular}

Notes: All regressions contain as explanatory variables a dummy for each of the 81 individual cities, in addition to the variables listed in the cell. Heteroscedasticity-consistent standard errors (White, 1980) are reported. Coefficients and standard errors on log distance and border are multiplied by $10^{3}$ (measure 1, 2, 3: specification 1), the coefficients and standard errors on distance, and distance squared are multiplied by $10^{6}$ and $10^{9}$ (measure 1: specification 2), respectively. In the specification named „Measure 1“, the dependent variable is the standard deviation of the one-month difference in relative prices. In the specification named „Measure 2 “, the dependent variable is the spread between the $10^{\text {th }}$ and 90th percentiles in the distribution of the one-month changes in relative prices. In the specification named „Measure 3“, the dependent variable is the two-month-ahead insample forecast error from an estimated AR(2) process (including 12 seasonal dummies). „Measure 4 “ is based on a specification where both sides of equation (1) where divided by log distance and hence the standard errors are proportional to log distance. Standard deviations are computed over the sample period from January 1995 to June 2000. There are 3240 observations in each regression. 
Table 2b:

Estimation Using Log Distance, Border and Exchange Rate Volatility, European City Pairs, Overall Period (Jan 1995-June 2000), Measure 1

\begin{tabular}{lrrrrrr} 
Variable & \multicolumn{1}{c}{ Coeff. } & Stde. & t-Stat. & Coeff. & Stde. & t-Stat. \\
\hline Log(Distance) & 1,33 & 0,04 & 29,3 & 1,04 & 0,05 & 22,5 \\
Border & 301,8 & 4,99 & 60,5 & 1,44 & 0,10 & 14,5 \\
Nom. Exrate & & & & 0,249 & 0,005 & 45,8 \\
Volatility & & & & & & \\
\hline$R^{2}$ & 0.871 & & & 0.880 & & \\
$R^{2}$ (adj.) & 0.868 & & & 0.877 & & \\
SEE $(* 1000)$ & 1.199 & & & 1.158 & & \\
\hline
\end{tabular}

Notes: All regressions contain as explanatory variables a dummy for each of the included individual in addition to the variables listed in the cells. Heteroscedasticity-consistent standard errors (White, 1980) are reported. Coefficients and standard errors on log distance and border are multiplied by $10^{3}$. The dependent variable is the standard deviation of the one-month difference in relative prices. Standard deviations are computed over the sample period from January 1995 to June 2000 (Exceptions: Italian Data are available from January 1996 only, Swiss Data end in May 2000). There are 3240 observations in the overall CPI regression. 
Table 3:

Estimation Using Log Distance Function, Overall Period (Jan 1995-July 2000) and EMS/ERM-Subperiods (Jan. 1995-Dec. 1998, Jan. 1999-July 2000), Volatility Measures 1 and 2

\begin{tabular}{|c|c|c|c|c|c|c|c|c|c|c|c|c|}
\hline \multirow[b]{3}{*}{ Variable } & \multicolumn{6}{|c|}{ Specification 1} & \multicolumn{6}{|c|}{ Specification 2} \\
\hline & \multicolumn{2}{|c|}{ Overall Period } & \multicolumn{2}{|c|}{ Subperiod 1} & \multicolumn{2}{|c|}{ Subperiod 2} & \multicolumn{2}{|c|}{ Overall Period } & \multicolumn{2}{|c|}{ Subperiod 1} & \multicolumn{2}{|c|}{ Subperiod 2} \\
\hline & Coeff. & Stder. & Coeff. & Stder. & Coeff. & Stder. & Coeff. & Stder. & Coeff. & Stder. & Coeff. & Stder. \\
\hline Log(Distance $)$ & 0,065 & 0,022 & 0,084 & 0,025 & 0,029 & 0,020 & 0,421 & 0,000 & 0,515 & 0,000 & 0,135 & 0,000 \\
\hline Distance sqr. & & & & & & & $-0,400$ & 0,000 & $-0,400$ & 0,000 & $-0,100$ & 0,000 \\
\hline Border ge-au & 1,587 & 0,035 & 1,744 & 0,041 & 1,210 & 0,041 & 1,604 & 0,034 & 1,765 & 0,040 & 1,221 & 0,040 \\
\hline Border ge-ch & 8,417 & 0,038 & 9,128 & 0,045 & 6,391 & 0,074 & 8,438 & 0,036 & 9,154 & 0,045 & 6,404 & 0,072 \\
\hline Border ge-por & 8,292 & 0,118 & 9,972 & 0,123 & 2,000 & 0,139 & 8,718 & 0,112 & 10,426 & 0,119 & 2,129 & 0,143 \\
\hline Border au-ch & 7,637 & 0,060 & 8,441 & 0,065 & 5,074 & 0,100 & 7,662 & 0,060 & 8,474 & 0,065 & 5,090 & 0,098 \\
\hline Border au-it & 6,074 & 0,030 & 7,710 & 0,036 & 0,944 & 0,031 & 6,092 & 0,029 & 7,732 & 0,035 & 0,955 & 0,030 \\
\hline Border au-sp & 6,907 & 0,047 & 8,224 & 0,055 & 1,682 & 0,042 & 7,096 & 0,053 & 8,423 & 0,061 & 1,745 & 0,050 \\
\hline Border au-po & 7,902 & 0,121 & 9,540 & 0,126 & 1,897 & 0,141 & 8,364 & 0,116 & 10,037 & 0,124 & 2,038 & 0,144 \\
\hline Border it-po & 4,367 & 0,115 & 5,504 & 0,118 & 1,338 & 0,137 & 4,727 & 0,107 & 5,889 & 0,112 & 1,448 & 0,139 \\
\hline Border sp-po & 5,730 & 0,110 & 6,872 & 0,112 & 1,367 & 0,133 & 5,765 & 0,091 & 6,909 & 0,093 & 1,379 & 0,129 \\
\hline $\mathrm{R}^{2}$ & 0.9915 & & 0.9913 & & 0.9918 & & 0.9920 & & 0.9501 & & 0.9502 & \\
\hline $\mathrm{R}^{2}$ (adj.) & 0.9912 & & 0.9911 & & 0.9915 & & 0.9918 & & 0.9485 & & 0.9487 & \\
\hline $\operatorname{SEE}(* 1000)$ & 0.3087 & & 0.3671 & & 0.3573 & & 0.2989 & & 0.3674 & & 0.3669 & \\
\hline
\end{tabular}

Notes: All regressions contain as explanatory variables a dummy for each of the 23 individual cities, in addition to the variables listed in the cell. Heteroscedasticity-consistent standard errors (White, 1980) are reported. Coefficients and standard errors on log distance, border, distance, and distance squared are multiplied by $10^{4}, 10^{6}, 10^{6}$, and $10^{9}$, respectively. In specification 1 , the dependent variable is the standard deviation of the one-month-ahead forecast error from the filtered relative price. In specification 2 , the dependent variable is the standard deviation of the one-month difference in the relative price. Standard deviations are computed over the sample period from January 1995 to July 2000. There are 3240 observations in each regression. 
Table 4a:

Estimation Using Log Distance Function, Overall Period (Jan 1995-July 2000) and EMS/ERM-Subperiods (Jan. 1995-Dec. 1998, Jan. 1999-June 2000), Disaggregate CPI Components, Volatility Measure 1

\begin{tabular}{|c|c|c|c|c|c|c|c|c|c|c|c|c|}
\hline \multirow[b]{3}{*}{ Variable } & \multicolumn{6}{|c|}{ Food } & \multicolumn{6}{|c|}{ Clothing } \\
\hline & \multicolumn{2}{|c|}{ Overall Period } & \multicolumn{2}{|c|}{ Subperiod 1} & \multicolumn{2}{|c|}{ Subperiod 2} & \multicolumn{2}{|c|}{ Overall Period } & \multicolumn{2}{|c|}{ Subperiod 1} & \multicolumn{2}{|c|}{ Subperiod 2} \\
\hline & Coeff. & Stder. & Coeff. & Stder. & Coeff. & Stder. & Coeff. & Stder. & Coeff. & Stder. & Coeff. & Stder. \\
\hline Log(Distance) & 0.230 & 0.035 & 0.248 & 0.040 & 0.218 & 0.042 & 0.474 & 0.178 & 0.410 & 0.177 & 0.633 & 0.198 \\
\hline Border ge-au & 1.836 & 0.055 & 2.199 & 0.063 & 0.907 & 0.076 & 2.494 & 0.310 & 2.774 & 0.309 & 1.252 & 0.322 \\
\hline Border ge-ch & 7.528 & 0.105 & 8.112 & 0.168 & 5.399 & 0.207 & - & - & - & - & - & - \\
\hline Border ge-it & 5.165 & 0.052 & 6.866 & 0.059 & 0.613 & 0.070 & 3.874 & 0.197 & 5.250 & 0.197 & -0.089 & 0.221 \\
\hline Border ge-sp & 6.549 & 0.098 & 7.763 & 0.112 & 2.431 & 0.092 & 5.473 & 0.276 & 7.053 & 0.276 & -0.272 & 0.315 \\
\hline Border ge-por & 6.748 & 0.179 & 8.077 & 0.203 & 2.251 & 0.184 & 14.040 & 1.105 & 10.957 & 0.662 & 19.504 & 1.999 \\
\hline Border au-ch & 5.882 & 0.119 & 5.962 & 0.185 & 5.785 & 0.202 & - & - & - & - & - & - \\
\hline Border au-it & 4.663 & 0.043 & 6.218 & 0.051 & 1.000 & 0.062 & 5.513 & 0.285 & 6.672 & 0.285 & 2.076 & 0.279 \\
\hline Border au-sp & 5.522 & 0.101 & 6.706 & 0.117 & 1.726 & 0.099 & 6.084 & 0.361 & 7.115 & 0.351 & 2.070 & 0.404 \\
\hline Border au-po & 5.654 & 0.185 & 6.914 & 0.210 & 1.739 & 0.184 & 9.339 & 1.222 & 7.876 & 0.770 & 14.564 & 2.062 \\
\hline Border ch-it & 9.897 & 0.106 & 11.745 & 0.168 & 4.598 & 0.220 & - & - & - & - & - & - \\
\hline Border ch-sp & 10.321 & 0.152 & 11.458 & 0.211 & 6.194 & 0.196 & - & - & - & - & - & - \\
\hline Border ch-po & 10.899 & 0.250 & 12.648 & 0.323 & 4.155 & 0.392 & - & - & - & - & - & - \\
\hline Border it-sp & 4.212 & 0.085 & 5.433 & 0.097 & 1.162 & 0.082 & 3.120 & 0.205 & 4.136 & 0.205 & -0.545 & 0.229 \\
\hline Border it-po & 4.007 & 0.178 & 5.309 & 0.201 & 1.082 & 0.175 & 16.234 & 1.098 & 11.169 & 0.657 & 20.993 & 1.963 \\
\hline Border sp-po & 4.399 & 0.179 & 5.311 & 0.200 & 1.122 & 0.178 & 14.805 & 1.067 & 10.202 & 0.602 & 22.260 & 1.967 \\
\hline $\mathrm{R}^{2}$ & 0.9632 & & 0.9639 & & 0.8859 & & 0.9632 & & 0.9594 & & 0.9684 & \\
\hline $\mathrm{R}^{2}$ (adj.) & 0.9620 & & 0.9628 & & 0.8823 & & 0.9621 & & 0.9582 & & 0.9674 & \\
\hline $\operatorname{SEE}(* 1000)$ & 0.6009 & & 0.6985 & & 0.7533 & & 2.6815 & & 2.4252 & & 3.1853 & \\
\hline
\end{tabular}

Notes: All regressions contain as explanatory variables a dummy for each of the individual cities (79 for food and 77 for clothing) in addition to the variables listed in the cell. Heteroscedasticity-consistent standard errors (White, 1980) are reported. Coefficients and standard errors of $\log$ distance and border are multiplied by 104 and 10, respectively. The dependent variable is the standard deviation of the two-month difference in the relative price. Standard deviations are computed over the sample period from January 1995 to July 2000. There are 3081 and 2926 observations in each regression for food and clothing, respectively. 
Table 4b:

Estimation Using Log Distance Function, Overall Period (Jan 1995-June 2000) and EMS/ERM-Subperiods (Jan. 1995-Dec. 1998, Jan. 1999-June 2000), Disaggregate CPI Components, Volatility Measures 1

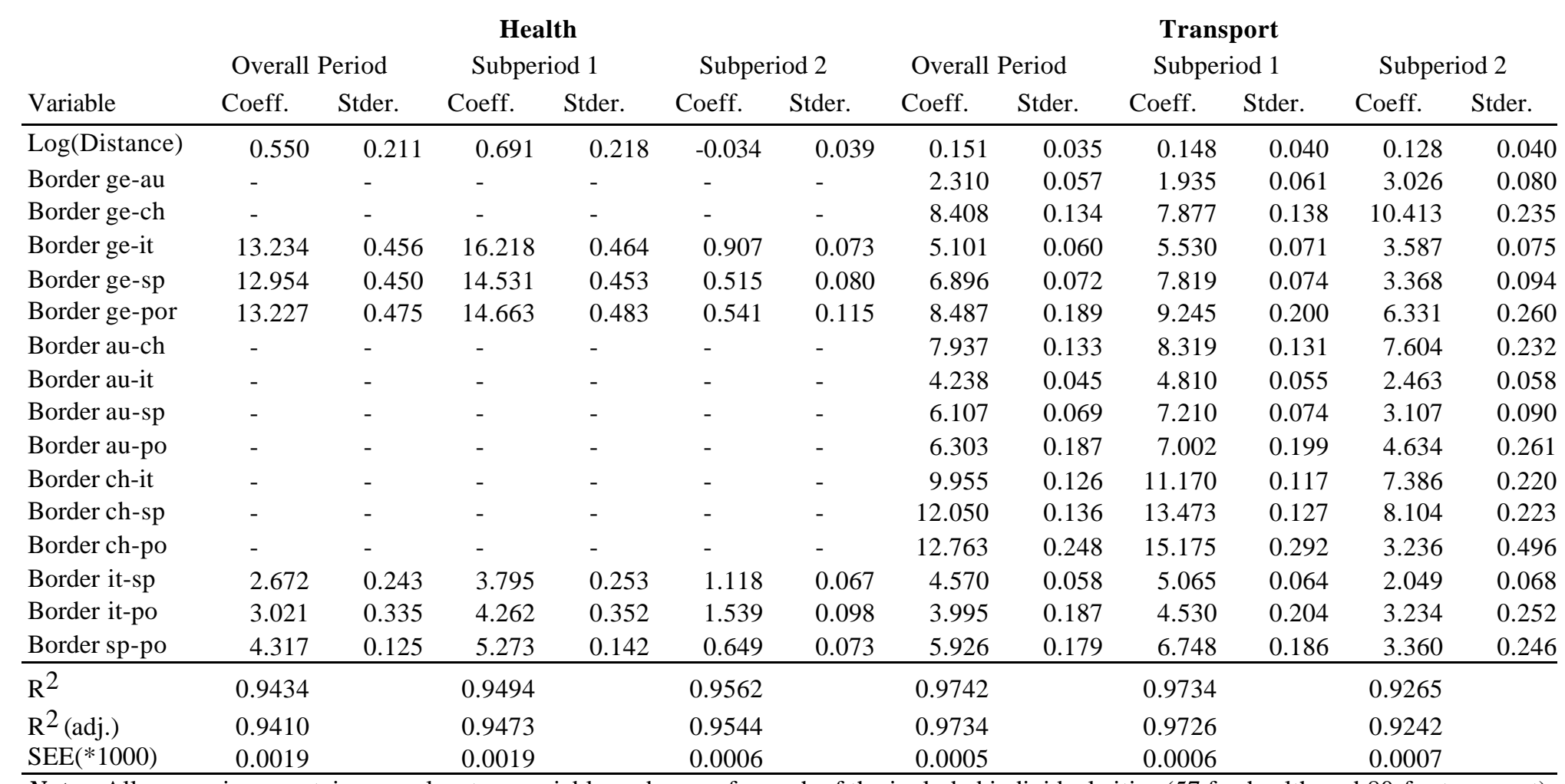

Notes: All regressions contain as explanatory variables a dummy for each of the included individual cities (57 for health and 80 for transport), in addition to the variables listed in the cells. Heteroscedasticity-consistent standard errors (White, 1980) are reported. Coefficients and standard errors on log distance and border are multiplied by $10^{3}$. The dependent variable is the standard deviation of the one-month difference in relative prices. Standard deviations are computed over the sample period from January 1995 to June 2000 (Exceptions: Italian Data are available from January 1996 only, Swiss Data end in May 2000). There are 1596 observations in the health regression and 3160 observations in the transport regression. 


\section{Table 4c:}

Estimation Using Log Distance Function, Overall Period (Jan 1995-June 2000) and EMS/ERM-Subperiods (Jan. 1995-Dec. 1998, Jan. 1999-June 2000), Disaggregate CPI Components, Volatility Measures 1

\begin{tabular}{|c|c|c|c|c|c|c|c|c|c|c|c|c|}
\hline \multirow[b]{3}{*}{ Variable } & \multicolumn{6}{|c|}{ Furniture } & \multicolumn{6}{|c|}{ Fuel } \\
\hline & \multicolumn{2}{|c|}{ Overall Period } & \multicolumn{2}{|c|}{ Subperiod 1} & \multicolumn{2}{|c|}{ Subperiod 2} & \multicolumn{2}{|c|}{ Overall Period } & \multicolumn{2}{|c|}{ Subperiod 1} & \multicolumn{2}{|c|}{ Subperiod 2} \\
\hline & Coeff. & Stder. & Coeff. & Stder. & Coeff. & Stder. & Coeff. & Stder. & Coeff. & Stder. & Coeff. & Stder. \\
\hline Border ge-au & - & - & - & - & - & - & - & - & - & - & - & - \\
\hline Border ge-ch & - & - & - & - & - & - & 6.809 & 0.141 & 7.245 & 0.204 & 5.301 & 0.275 \\
\hline Border ge-it & 4.932 & 0.050 & 6.273 & 0.056 & 0.749 & 0.062 & 3.850 & 0.119 & 4.941 & 0.154 & 1.091 & 0.091 \\
\hline Border au-ch & - & - & - & - & - & - & - & - & - & - & - & - \\
\hline Border au-it & - & - & - & - & - & - & - & - & - & - & - & - \\
\hline Border au-sp & - & - & - & - & - & - & - & - & - & - & - & - \\
\hline Border au-po & - & - & - & - & - & - & - & - & - & - & - & - \\
\hline Border ch-it & - & - & - & - & - & - & 10.258 & 0.110 & 12.211 & 0.165 & 4.827 & 0.283 \\
\hline Border sp-po & 4.432 & 0.096 & 5.422 & 0.121 & 0.718 & 0.135 & 5.039 & 0.166 & 6.542 & 0.190 & 1.685 & 0.139 \\
\hline $\mathrm{R}^{2}$ & 0.9755 & & 0.9759 & & 0.9759 & & 0.9447 & & 0.9357 & & 0.9173 & \\
\hline $\mathrm{R}^{2}$ (adj.) & 0.9745 & & 0.9749 & & 0.9749 & & 0.9424 & & 0.9331 & & 0.9139 & \\
\hline $\operatorname{SEE}(* 1000)$ & 0.0004 & & 0.0005 & & 0.0005 & & 0.0007 & & 0.0009 & & 0.0007 & \\
\hline
\end{tabular}

Notes: All regressions contain as explanatory variables a dummy for each of the included individual cities (57 for furniture and 60 for fuel), in addition to the variables listed in the cells. Heteroscedasticity-consistent standard errors (White, 1980) are reported. Coefficients and standard errors on $\log$ distance and border are multiplied by $10^{3}$. The dependent variable is the standard deviation of the one-month difference in relative prices. Standard deviations are computed over the sample period from January 1995 to June 2000 (Exceptions: Italian Data are available from January 1996 only, Swiss Data end in May 2000). There are 1596 observations in the furniture regression and 1770 observations in the fuel regression. 
Table 4d:

Estimation Using Log Distance Function, Overall Period (Jan 1995-June 2000) and EMS/ERM-Subperiods (Jan. 1995-Dec. 1998, Jan. 1999-June 2000), Disaggregate CPI Components, Volatility Measures 1

\begin{tabular}{|c|c|c|c|c|c|c|c|c|c|c|c|c|}
\hline \multirow[b]{2}{*}{ Variable } & \multicolumn{6}{|c|}{ Education } & \multicolumn{2}{|c|}{ Overall Period } & \multicolumn{2}{|c|}{ Subperiod 1} & \multicolumn{2}{|c|}{ Subperiod 2} \\
\hline & Coeff. & Stder. & Coeff. & Stder. & Coeff. & Stder. & Coeff. & Stder. & Coeff. & Stder. & Coeff. & Stder. \\
\hline Border ge-au & 16.701 & 0.129 & 19.369 & 0.153 & 7.550 & 0.085 & & & & & & \\
\hline Border ge-ch & - & - & - & - & - & - & & & & & & \\
\hline Border ge-it & 10.908 & 0.112 & 11.817 & 0.134 & 9.902 & 0.083 & & & & & & \\
\hline Border au-ch & - & - & - & - & - & - & & & & & & \\
\hline Border au-it & 17.505 & 0.131 & 21.232 & 0.160 & 7.676 & 0.061 & & & & & & \\
\hline Border au-sp & 21.852 & 0.174 & 25.641 & 0.209 & 7.948 & 0.095 & & & & & & \\
\hline Border au-po & 19.691 & 0.365 & 22.898 & 0.444 & 7.746 & 0.135 & & & & & & \\
\hline Border ch-it & - & - & - & - & - & - & & & & & & \\
\hline Border sp-po & 3.940 & 0.269 & 4.935 & 0.332 & 0.167 & 0.119 & & & & & & \\
\hline $\mathrm{R}^{2}$ & 0.9794 & & 0.9785 & & 0.9717 & & & & & & & \\
\hline $\mathrm{R}^{2}$ (adj.) & 0.9788 & & 0.9778 & & 0.9708 & & & & & & & \\
\hline $\operatorname{SEE}(* 1000)$ & 0.0012 & & 0.0014 & & 0.0007 & & & & & & & \\
\hline
\end{tabular}

Notes: All regressions contain as explanatory variables a dummy for each of the included individual cities (75) in addition to the variables listed in the cells. Heteroscedasticity-consistent standard errors (White, 1980) are reported. Coefficients and standard errors on log distance and border are multiplied by $10^{3}$. The dependent variable is the standard deviation of the one-month difference in relative prices. Standard deviations are computed over the sample period from January 1995 to June 2000 (Exceptions: Italian Data are available from January 1996 only). There are 2850 observations in the education regression. 
Table 5:

Estimation Using Log Distance Function, Overall Period (Jan 1991-June 2000) and EMS/ERM-Subperiods (Jan. 1991-Dec. 1994, Jan. 1995-Dec. 1998, Jan. 1999-June 2000), Volatility Measures 1 and 2

\begin{tabular}{|c|c|c|c|c|c|c|c|c|c|c|c|c|c|c|c|c|}
\hline \multirow[b]{3}{*}{ Variable } & \multicolumn{8}{|c|}{ Measure 1} & \multicolumn{8}{|c|}{ Measure 2} \\
\hline & \multicolumn{2}{|c|}{ Overall Sample } & \multicolumn{2}{|c|}{ Subperiod 1} & \multicolumn{2}{|c|}{ Subperiod 2} & \multicolumn{2}{|c|}{ Subperiod 3} & \multicolumn{2}{|c|}{ Overall Sample } & \multicolumn{2}{|c|}{ Subperiod 1} & \multicolumn{2}{|c|}{ Subperiod 2} & \multicolumn{2}{|c|}{ Subperiod 3} \\
\hline & Coeff. & Stde. & Coeff. & Stde. & Coeff. & Stde. & Coeff. & Stde. & Coeff. & Stde. & Coeff. & Stde. & Coeff. & Stde. & Coeff. & Stde. \\
\hline Log(Distance) & 0.096 & 0.029 & 0.173 & 0.029 & 0.088 & 0.044 & 0.022 & 0.035 & 0.224 & 0.083 & 0.364 & 0.136 & 0.162 & 0.126 & 0.099 & 0.091 \\
\hline Border we-ea & 11.567 & 0.241 & 18.407 & 0.366 & 0.542 & 0.097 & 0.130 & 0.115 & 1.119 & 0.214 & 2.709 & 0.348 & 0.436 & 0.281 & -0.028 & 0.307 \\
\hline Border we-au & 2.139 & 0.043 & 2.627 & 0.055 & 2.261 & 0.053 & 1.037 & 0.065 & 5.966 & 0.134 & 7.497 & 0.159 & 5.856 & 0.185 & 2.658 & 0.175 \\
\hline Border we-ch & 8.477 & 0.051 & 8.712 & 0.083 & 8.721 & 0.070 & 8.169 & 0.074 & 20.838 & 0.339 & 20.263 & 0.414 & 23.556 & 0.367 & 19.357 & 0.210 \\
\hline Border ea-au & 11.412 & 0.244 & 18.476 & 0.371 & 1.794 & 0.099 & 0.940 & 0.098 & 6.075 & 0.194 & 9.120 & 0.292 & 4.608 & 0.259 & 2.437 & 0.286 \\
\hline Border ea-ch & 15.308 & 0.247 & 21.530 & 0.378 & 8.580 & 0.115 & 8.040 & 0.107 & 21.020 & 0.318 & 22.199 & 0.569 & 21.683 & 0.417 & 19.970 & 0.325 \\
\hline Border au-ch & 8.276 & 0.050 & 9.426 & 0.068 & 8.258 & 0.082 & 6.702 & 0.105 & 19.996 & 0.179 & 23.707 & 0.271 & 18.702 & 0.268 & 15.346 & 0.285 \\
\hline$R^{2}$ & 0.9967 & & 0.9977 & & 0.9837 & & 0.9690 & & 0.9881 & & 0.9836 & & 0.9673 & & 0.9481 & \\
\hline$R^{2}(\operatorname{adj})$. & 0.9965 & & 0.9975 & & 0.9824 & & 0.9665 & & 0.9872 & & 0.9823 & & 0.9646 & & 0.9440 & \\
\hline $\operatorname{SEE}(* 1000)$ & 0.0003 & & 0.0004 & & 0.0004 & & 0.0005 & & 0.0008 & & 0.0012 & & 0.0013 & & 0.0015 & \\
\hline
\end{tabular}

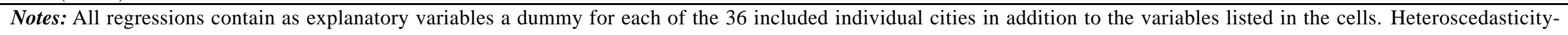

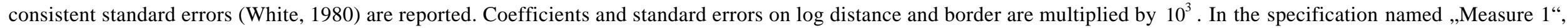

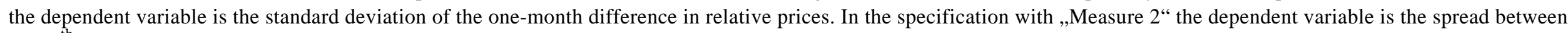

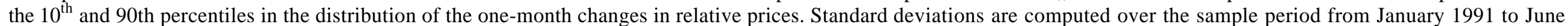
2000. There are 258 observations in all regressions. 


\section{Appendix Table 1}

\section{Categories of Goods}

\begin{tabular}{|c|c|c|c|c|c|}
\hline Germany & Austria & Switzerland & Italy & Spain & Portugal \\
\hline All Items & All Items & All Items & All Items & All Items & All Items \\
\hline $\begin{array}{l}0.13126 *(\text { Food and Non } \\
\text { Alcoholic Beverages })+ \\
0.04167 * \text { (Alcoholic } \\
\text { Beverages and Tobacco) }\end{array}$ & $\begin{array}{l}0.1526^{*}(\text { Food and } \\
\text { Beverages })+ \\
0.02033^{*}(\text { Tobacco })\end{array}$ & $\begin{array}{l}\text { Food, Beverages and } \\
\text { Tobacco }\end{array}$ & $\begin{array}{l}0.16565^{*}(\text { Food and Non } \\
\text { Alcoholic Beverages })+ \\
0.027649 *(\text { Alcoholic } \\
\text { Beverages and Tobacco) }\end{array}$ & $\begin{array}{l}\text { Food, Beverages } \\
\text { and Tobacco }\end{array}$ & $\begin{array}{l}0.13126^{*}(\text { Food and Non } \\
\text { Alcoholic Beverages })+ \\
0.04167^{*}(\text { Alcoholic } \\
\text { Beverages and Tobacco) }\end{array}$ \\
\hline Clothing and footwear & Clothing & n.a. & Clothing and footwear & Clothing & Clothing and footwear \\
\hline $\begin{array}{l}\text { Housing, water, } \\
\text { electricity, gas and other } \\
\text { fuels }\end{array}$ & n.a. & $\begin{array}{l}\text { Household Appliances } \\
\text { (Light and Water) }\end{array}$ & $\begin{array}{l}\text { Housing, water, } \\
\text { electricity, gas and other } \\
\text { fuels }\end{array}$ & $\begin{array}{l}\text { Household } \\
\text { Appliances (Light } \\
\text { and Water) }\end{array}$ & $\begin{array}{l}\text { Housing, water, } \\
\text { electricity, gas and other } \\
\text { fuels }\end{array}$ \\
\hline $\begin{array}{l}\text { Furnishings, household } \\
\text { equip. and routine maint. } \\
\text { of the house }\end{array}$ & n.a. & n.a. & $\begin{array}{l}\text { Furnishings, household } \\
\text { equip. and routine maint. } \\
\text { of the house }\end{array}$ & $\begin{array}{l}\text { Housing and } \\
\text { Repairs }\end{array}$ & $\begin{array}{l}\text { Furnishings, household } \\
\text { equip. and routine maint. } \\
\text { of the house }\end{array}$ \\
\hline Health & n.a. & n.a. & Health & $\begin{array}{l}\text { Medicine and } \\
\text { Personal Care }\end{array}$ & Health \\
\hline $\begin{array}{l}0.13882 * \text { Transport }+ \\
0.02266 * \text { Communication }\end{array}$ & Transportation & $\begin{array}{l}\text { Transport and } \\
\text { Communication }\end{array}$ & $\begin{array}{l}0.143223 * \text { Transport }+ \\
0.02686 * \text { Communication }\end{array}$ & $\begin{array}{l}\text { Transport and } \\
\text { Communication }\end{array}$ & $\begin{array}{l}0.13882 * \text { Transport }+ \\
0.02266 * \text { Communication }\end{array}$ \\
\hline $\begin{array}{l}0.00651^{*} \text { Education }+ \\
0.10357^{*}(\text { Recreation and } \\
\text { Culture) }\end{array}$ & $\begin{array}{l}\text { Education and } \\
\text { Entertainment }\end{array}$ & n.a. & $\begin{array}{l}0.010284 * \text { Education }+ \\
0.079206 *(\text { Recreation } \\
\text { and Culture) }\end{array}$ & $\begin{array}{l}\text { Education and } \\
\text { Entertainment }\end{array}$ & $\begin{array}{l}0.00651 * \text { Education }+ \\
0.10357 *(\text { Recreation and } \\
\text { Culture })\end{array}$ \\
\hline $\begin{array}{l}\text { Source: Statistical } \\
\text { Offices of the } \\
\text { "Bundesländer" }\end{array}$ & $\begin{array}{l}\text { Source: Statistic } \\
\text { Austria (Östat) }\end{array}$ & $\begin{array}{l}\text { Source: Statistical } \\
\text { Offices of Basel, } \\
\text { Bern, Geneve, Zürich }\end{array}$ & $\begin{array}{l}\text { Source: Instituto } \\
\text { Nazionale di Statistica } \\
\text { (Istat) }\end{array}$ & $\begin{array}{l}\text { Source: Instituto } \\
\text { Nacional de } \\
\text { Estadistica (Ine) } \\
\end{array}$ & $\begin{array}{l}\text { Source: Instituto } \\
\text { Nacional de Estatistica } \\
\text { (Ine) }\end{array}$ \\
\hline
\end{tabular}




\section{Appendix Table 2}

Included Region/Cities

\section{Germany (12 Regions)}

Baden-Württemberg (Stuttgart), Bayern (München), Berlin, Brandenburg (Potsdam), Hessen (Wiesbaden), Mecklenburg-Vorpommern (Schwerin), Niedersachen (Hannover), Nordrhein-Westfalen (Düsseldorf), Saarland (Saarbrücken), Sachsen (Dresden), Sachsen-Anhalt (Magdeburg), Thüringen (Erfurt)

\section{Austria (20 Cities)}

Amstetten, Baden, Bregenz, Dornbirn, Eisenstadt, Feldkirch, Graz, Innsbruck, Kapfenberg, Klagenfurt, Krems, Linz, Salzburg, Steyr, St.Poelten, Villach, Wels, Wien, Wiener Neustadt, Wolfsberg

\section{Switzerland (4 Cities)}

Basel, Bern, Genf, Zürich

\section{Italy (20 Regions, 96.01 - 00.06)}

Aosta, Bologna, Bolzano, Brindisi, Cosenza, Como, Genoa, Grosseto, Milano, Naples, Palermo, Pisa, ReggigideCalabria, Rome, SanMarino, Terni, Trieste, Turin, Venice, Verona

\section{Spain (18 Regions)}

Andalucia (Seville), Aragon (Saragossa), Principado de Asturias (Oviedo), Baleares (PalmadeMallorca), Canarias (LaPalma), Caabria (Santander), Castilla y Leon (Valladolid), Castilla La Mancha (Albacete), Cataluna (Barcelona), Ceuta y Melilla (Ceuta), Extremadura (Badajoz), Galicia (LaCoruna), Communidad Madrid (Madrid), Cummunidad Murcia (Murcia), Navarra (Pamplona), Pais Vasco (SanSebastian), La Rioja (Logrona), Communidad Valenicana (Valencia)

\section{Portugal (7 Regions)}

Acores (Angrado Heroismo), Algarve (Faro), Altenejo (Evora), Centro (Coimbra), Lisbon (Lisbon), Madeira (Funchal), Norte (Vila Real) 


\section{CFS Working Paper Series:}

\begin{tabular}{lll} 
No. & Author(s) & Title \\
\hline $2001 / 02$ & Roland Beck & $\begin{array}{l}\text { Do Country Fundamentals Explain Emerging } \\
\text { Market Bond Spreads? }\end{array}$ \\
$2001 / 03$ & $\begin{array}{l}\text { Markus Kern } \\
\text { Bernd Rudolph }\end{array}$ & $\begin{array}{l}\text { Comparative Analysis of Alternative Credit } \\
\text { Risk Models - An Application on German } \\
\text { Middle Market Loan Portfolios - }\end{array}$ \\
$2001 / 04$ & $\begin{array}{l}\text { Antje Brunner } \\
\text { Jan Pieter Krahnen }\end{array}$ & $\begin{array}{l}\text { Multiple Lenders and Corporate Distress: } \\
\text { Evidence on Debt Restructuring }\end{array}$ \\
$2001 / 05$ & $\begin{array}{l}\text { Ralf Ewert } \\
\text { Andrea Szczesny }\end{array}$ & $\begin{array}{l}\text { Countdown for the New Basle Capital Accord. } \\
\text { Are German Banks Ready for the Internal } \\
\text { Ratings-Based Approach? }\end{array}$ \\
$2001 / 06$ & Bernd Kaltenhäuser & $\begin{array}{l}\text { Explaining the Dollar-Euro Rate: Do Stock } \\
\text { Market Returns Matter? }\end{array}$ \\
$2001 / 07$ & $\begin{array}{l}\text { Guenter Beck } \\
\text { Axel A. Weber }\end{array}$ & $\begin{array}{l}\text { How wide are European borders? New Evidence } \\
\text { on the Integration Effects of Monetary Unions }\end{array}$ \\
$2001 / 08$ & $\begin{array}{l}\text { Yunus Aksoy } \\
\text { Tomasz Piskorski }\end{array}$ & Domestic Money and US Output and Inflation \\
\end{tabular}

2001/09 Elke Hahn

Core Inflation in the Euro Area: Evidence from the Structural VAR Approach

2001/10 Olaf Ehrhardt

Eric Nowak

2001/11 Daniel Gross

2001/12 Daniel Gross

2001/13 Guenter Beck

Axel A. Weber
Private Benefits and Minority Shareholder Expropriation - Empirical Evidence from IPOs of German Family-Owned Firms

Country-Specific and Global Shocks in the Business Cycle

Trade Flows and the International Business Cycle

Economic Integration and the Exchange Rate Regime: How Damaging are Currency Crises?

Copies of working papers are available at the Center for Financial Studies or can be downloaded (http://www.ifk-cfs.de). 